\author{
Desiderio J. GARCÍA-ALMEDIA * \\ William C. GARTNER **
}

\title{
MODEL KONKURENTNOSTI U TURISTIČKIM DESTINACIJAMA NEMATERIJALNE KULTURNE BAŠTINE SA STAJALIŠTA TEMELJENOG NA ZNANJU
}

\section{A MODEL OF COMPETITIVENESS IN INTANGIBLE CULTURAL HERITAGE TOURISM DESTINATIONS FROM THE KNOWLEDGE-BASED VIEW}

\begin{abstract}
SAŽETAK: U ovom radu predstavljen je model nematerijalne kulturne baštine sa stajališta temeljenog na znanju kojim se proučava njezina uloga u konkurentnosti destinacije. Prvo se razmatra pojam nematerijalne kulturne baštine i njen odnos s turizmom. Zatim slijedi osvrt na značaj konkurentnosti destinacije u kontekstu nematerijalne baštine i potencijala koji će se analizirati u okviru stajališta temeljenog na znanju. Kako je pojam održive konkurentske prednosti ključan u tom okruženju, važno je raspraviti odnose oskudnosti, relevantnosti, autentičnosti vezane uz mjesto, kratkoročne zaštite i prijenosa inherentnog znanja o nematerijalnoj kulturnoj baštini. Na prednostima održivog razvoja temeljenim na nematerijalnoj kulturnoj baštini zasniva se generiranje renti, ali one bi trebale barem djelomično pripadati lokalnoj zajednici/glavnim dionicima u destinaciji.

KLJUČNE RIJEČI: nematerijalna kulturna baština, znanje, konkurentnost, kulturni turizam, dobrobit zajednice

ABSTRACT: This work presents a model of intangible cultural heritage from a knowledge-based view that studies its role in destination competitiveness. Firstly, the concept of intangible cultural heritage and its relationship with tourism are reviewed. Next, the importance of destination competitiveness in the intangible heritage context and the potential to be analyzed under the framework of the knowledge-based view are addressed. As the concept of sustainable competitive advantage is key in that setting, the conditions of scarcity, relevance, place-embedded authenticity, short-term protection, and transfer of the underlying knowledge of intangible cultural heritage are discussed. Intangible cultural heritage-based sustainable competitive advantages are the basis to generate rents, but those rents should be at least partially appropriated by the local community/key stakeholders at the destination.
\end{abstract}

KEY WORDS: intangible cultural heritage, knowledge, competitiveness, cultural tourism, community wellbeing

\footnotetext{
* Professor Desiderio J. García-Almeida, University of Las Palmas de Gran Canaria, Las Palmas de Gran Canaria, Spain, e-mail: dj.garcia@ulpgc.es

** Professor William C. Gartner, University of Minnesota, St. Paul, Minnesota, USA, e-mail: wcg@umn.edu
} 


\section{UVOD}

Posljednjih godina nematerijalna kulturna baština razmatra se intenzivno u znanstvenoj literaturi, a termin se češće rabi i dobiva na znanstvenoj relevantnosti naročito nakon Kongresa za očuvanje nematerijalne kulturne baštine kojeg je 2003. godine organizirala Organizacija Ujedinjenih naroda za obrazovanje, znanost i kulturu (UNESCO). Akademska rasprava u početku je bila usmjerena na pojam nematerijalne kulturne baštine, ali su u zadnje vrijeme istraživačke teme postale analize njezine uloge i potencijala.

Nematerijalna kulturna baština odnosi se na prakse, manifestacije/mentalna predočavanja, izraze, znanje i vještine koje pripadaju zajednicama i koje drže određeni članovi tih zajednica (Cominelli i Greffe, 2012). To uključuje sve suvremene prikaze stvaralačkih aktivnosti ljudi koje se nasljeđuju od prethodnih generacija i koje se smatraju cijenjenima u skupinama ili društvima općenito i koje se stoga čuvaju u sadašnjem trenutku i prenose budućim generacijama (Pereira Roders i van Oers, 2011). Spomenuti autori (2011) ističu da nasljeđe može potaknuti lokalna i nacionalna gospodarstva i kreirati zapošljavanje privlačenjem turista i investicija. Nematerijalna kulturna baština značajna je imovina koja postaje glavni resurs za neke turističke destinacije te može povećati njihovu konkurentnost. Prema UNWTO-u (2012), nedostatak sveobuhvatnih strategija upravljanja brojnim dimenzijama proizvoda nematerijalne kulturne baštine predstavlja izazove i zamagljuje mogućnosti za zajednice i ostale dionike.

Zbog svoje nematerijalne prirode, nematerijalna kulturna baština smatra se znanjem. $\mathrm{U}$ tom smislu, stajalište temeljeno na znanju daje čvrstu teoretsku podlogu za analizu ovog elementa kao osnove za konkurentske prednosti pa stoga i jačanje konkurentnosti destinacije. Ipak, ideje i okviri upravljanja

\section{INTRODUCTION}

In recent years intangible cultural heritage has been addressed in the academic literature. The Convention for the Safeguarding of the Intangible Cultural Heritage organized by the United Nations Educational, Scientific and Cultural Organization (UNESCO) in 2003 increased the exposure of the term and consequently the academic relevance of the topic. The academic discussion initially focused on the concept of intangible cultural heritage, but more recently, several researchers have analyzed its role and potential.

Intangible cultural heritage concerns the practices, representations, expressions, knowledge and skills that belong to communities and are held by specific members in that community (Cominelli and Greffe, 2012). It includes all contemporary demonstrations of human creative activity that are inherited from previous generations and considered valuable by groups or society at large, and therefore preserved in the present and transmitted to future generations (Pereira Roders and van Oers, 2011). From their review, Pereira Roders and van Oers (2011) emphasize heritage can boost local and national economies and create jobs by attracting tourists and investment. Intangible cultural heritage is a relevant asset to become the main resource for some tourism destinations, and it can reinforce its competitiveness. For the World Tourism Organisation (2012), the lack of comprehensive management strategies that address the numerous dimensions of intangible cultural heritage products creates challenges and overlooks opportunities for communities and other stakeholders.

Due to its intangible nature, intangible cultural heritage can be seen as knowledge. In that sense, the knowledge-based view provides a solid theoretical background to analyze this element as the basis of competitive advantages and, hence, to improve destination competitiveness. Nevertheless, the ideas and frameworks 
znanjem iz literature trebaju se prilagoditi za artikulaciju na makro-razini u destinacijama (Cooper, 2006).

Upravljanje kulturnom baštinom kao imovinom bitno je područje propitivanja i istraživanja. Turizam baštine zahtijeva strateško planiranje društveno-psiholoških potreba i percepcija turista kako bi se potaknulo njegovo planiranje i upravljanje (Datta, Bigham, Zou i Hill, 2015). Literatura na temu upravljanja uslugama (npr. García-Almeida, 2011) dopušta isticanje više razine složenosti u upravljanju nematerijalnom baštinom u usporedbi s upravljanjem materijalnom baštinom koja se temelji na izazovima značajki vezanih uz nematerijalnost. Ipak, i materijalna i nematerijalna baština moraju ispuniti zahtjeve održivosti za kontinuiranu uporabu kojom se osiguravaju dugoročne koristi za lokalne stanovnike i ekonomske dionike turizma.

Odnos između kulturne baštine i konkurentnosti, s obzirom na turizam, ostaje znatno neistražen (Alberti i Giusti, 2012), a taj jaz u znanstvenoj literaturi još je dublji u kontekstu nematerijalne kulturne baštine. Štoviše, Alberti i Giusti (2012) tvrde da su empirijske spoznaje o temi konkurentnosti kulturne baštine još uvijek anegdotalne i deskriptivne, a studije slučajeva tek u začetku. Jedina razvijena značajka u ovom kontekstu je analiza oblikovanja i razvoja kulturnih klastera i njihov utjecaj na konkurentnost, kao i napori UNWTO-a (2012) u rješavanju problema integracije nematerijalne kulturne baštine u razvoj turističkog proizvoda.

U ovom radu propituje se uloga nematerijalne kulturne baštine u turističkim aktivnostima i jačanju konkurentnosti destinacije. Konkretno, utvrđuju se i razmatraju uvjeti pod kojima nematerijalno znanje stvara održive konkurentske prednosti u ovom kontekstu. To bi moglo dovesti do stvaranja modela konkurentnosti destinacija koje se temelje na nematerijalnoj kulturnoj baštini. UNWTO (2012) zastupa isto stajalište kada analizira of knowledge management in the literature need to be adapted for their macro-level articulation at destinations (Cooper, 2006).

The management of cultural heritage assets is a relevant field of inquiry and research. Heritage tourism requires strategic planning considering tourists' social-psychological needs and perceptions in order to drive its planning and management (Datta, Bigham, Zou and Hill, 2015). The literature on service management (e.g., García-Almeida, 2011) allows for pointing out the higher level of complexity in managing intangible heritage compared to the management of tangible heritage based on the challenges of the characteristics associated to intangibility. Yet both tangible and intangible heritage must meet sustainability requirements for continued use providing long-term benefits to community residents and tourism's economic stakeholders.

The relationship between cultural heritage and competitiveness regarding tourism remains vastly unexplored (Alberti and $\mathrm{Gi}$ usti, 2012), and this gap in the academic literature is even more acute in the intangible cultural heritage context. Moreover, Alberti and Giusti (2012) assert that the empirical evidence on the topic of cultural heritage and competitiveness is still anecdotal and descriptive, and cases are still in an embryonic stage. The only developed aspect in this context is the analysis of the formation and development of cultural clusters and their impact on competitiveness, and the efforts of the UNWTO (2012) to tackle issues of the integration of intangible cultural heritage into tourism product development.

This work attempts to review the role intangible cultural heritage can play in tourism activities and the improvement of destination competitiveness. Specifically, the conditions of intangible knowledge to create sustainable competitive advantages in this context are identified and discussed. This would lead to the creation of a model of competitiveness for intangible cultural heritage-based destina- 
nematerijalnu kulturnu baštinu i njezin turistički potencijal i navodi da je krajnji cilj strateških aktivnosti destinacije identificirati $\mathrm{i}$ iskoristiti atribute proizvoda kojima postiže održivu prednost na tržištu. Ipak, ova studija ide i dalje razmatranjem prirode i uvjeta dugoročne valjanosti konkurentske prednosti temeljene na nematerijalnoj kulturnoj baštini prema čvrstom upravljačkom okviru: stajalištu temeljenom na znanju.

\section{NEMATERIJALNA KULTURNA BAŠTINA I TURIZAM}

Činjenica da je posljednjih godina kulturni turizam postao predmetom sve većeg interesa istraživača nije urodila isto tako rastućim brojem akademskih članaka (Watson, Waterton i Smith, 2012). Jedan od novijih oblika kulturnog turizma je nematerijalni kulturni turizam. Tako je u zadnjih desetak godina nematerijalna kulturna baština postala zanimljivo područje istraživanja (Pfeilstetter, 2015), iz čega proizlazi jasna potreba za održivim razvojem ovog područja, osobito u odnosu na turističke aktivnosti.

Afirmacija kulturne baštine kao predmeta razvila se njezinim uvrštavanjem na popis prema percepciji koja se temelji na kapacitetu predmeta da predstavi određene vrijednosti koje lokalna zajednica smatra baštinom (Vecco, 2010). Tradicionalni pristup bio je izravno orijentiran na prepoznavanje dragocjenosti materijalnih kulturnih proizvoda, ali kako Vecco (2010) navodi, razvojem teoretskog okvira stvoreni su temelji za prepoznavanje nematerijalne kulturne baštine kao podvrste kulturne baštine. Štoviše, neka društva doživljavaju baštinu na integrirani način, čime se razlika između nematerijalne i materijalne baštine čini neadekvatnom, pa čak i nelogičnom (Harrison i Rose, 2010). Na primjer, Kranjčević i Gartner (2019) razmatrali su tradicionalnu vinsku arhitekturu u Hrvatskoj kao materijalnu baštinu. Iako su fizički objekti primjeri materijalne kulturne tions. The UNWTO (2012) adopts the same view when it analyses intangible cultural heritage and its tourism potential, and it states that the ultimate goal of strategic destination activities is to identify and exploit the attributes of a product that give it a sustainable competitive advantage in the marketplace. However, this study goes beyond by reflecting the nature and conditions of long-term validity of the intangible cultural heritage-based competitive advantage from a solid management framework: the knowledge-based view.

\section{INTANGIBLE CULTURAL HERITAGE AND TOURISM}

Although cultural tourism has arisen as a growing research interest in recent years, this has not resulted into a balanced corpus of critical academic studies (Watson, Waterton and Smith, 2012). One of the emerging aspects of cultural tourism is intangible cultural tourism. Thus, intangible cultural heritage has become an interesting field of research in the last decade (Pfeilstetter, 2015), and the need for sustainable development in this area, especially related to tourism activities, is clear.

The recognition of cultural heritage as an object has evolved from its inclusion in a list to a perspective based on the capacity of the object to represent certain values that have led society in a region to consider it as heritage (Vecco, 2010). The traditional approach was directly oriented to recognize the value of tangible cultural products, but as Vecco (2010) notes, the evolution into a theoretical framework has set the basis to recognize intangible cultural heritage as a subset of cultural heritage. Moreover, some societies perceive heritage in an integrated fashion, which makes the distinction of intangible and tangible heritage non-adequate and even illogical (Harrison and Rose, 2010). For example, Kranjčević and Gartner (2019) examined traditional wine architecture in Croatia as a tangible cultural asset. Although physical structures are examples of tangible 
baštine, njihovo značenje poprima nematerijalnu vrijednost kada ga se sagledava kao integrirani dio povijesnog razvoja nekog područja. Upravo u stjecištu ovih dvaju koncepata, povijesti i razvoja, definira se nematerijalna kulturna baština koju predstavljaju fizički objekti. I materijalna i nematerijalna kulturna baština dio su onoga što Tasci i Gartner (2007) zovu „kapitalom imidža“ neke destinacije.

Za razliku od nesporazuma i problema s terminima kao što su npr. tradicionalna kultura, običaji ili folklor, termin ,nematerijalna kulturna baština" doživio je sveopće prihvaćanje (Duvelle, 2013). Datta et al. (2015) tvrde da su okolišna mjesta nematerijalne baštine nematerijalne manifestacije povijesti i kulture, među ostalima, putem plesa, pjesme, umjetničkog stila i audio-vizualnih prezentacija. Cominelli i Greffe (2012) tvrde da nematerijalna kulturna baština ima dvije relevantne dimenzije: tehničku, koja integrira njezina praktična znanja i iskustva te ju tako dovodi do današnjeg shvaćanja i društvene dimenzije koja se odnosi na dinamičko viđenje znanja u kontekstu interakcije i razvoja sudionika u društvenom ekosustavu.

Prekretnica u proučavanju nematerijalne kulturne baštine, a vjerojatno i početak njezine integracije u moderno razmišljanje, bila je Konvencija o zaštiti nematerijalne kulturne baštine koja se održala u Parizu 2003. godine $u$ organizaciji UNESCO-a. Mnogi smatraju da je konačni tekst Konvencije, koji je uslijedio nakon prvih nastojanja na zaštiti folklora (Aikawa, 2004) i diskusija, središnji element sadašnjeg zanimanja za ovu vrstu baštine.

Nematerijalna kulturna baština može imati čvrste značajke kako bi postala središna atrakcija za brojne segmente turističkih potrošača. Potraga za iskustvima i znanjem dalekih ili različitih stvarnosti može poslužiti kao osnova za odluku o posjeti nekog prostora u kojem se nalazi percipirana dragocjena nematerijalna kulturna baština, iako mogu postojati i neke druge vrste motivacije cultural heritage, their meaning takes on an intangible value when considered as part of the integrated historical development of an area. It is the meeting of these two concepts, history and development, that define the intangible cultural heritage represented by the physical structures. Both tangible and intangible cultural heritage constitute part of what Tasci and Gartner (2007) refer to the 'image capital' of a destination.

Contrary to the misunderstandings and problems with terms, such as traditional culture, customs or folklore, the term 'intangible cultural heritage' has become universally adopted (Duvelle, 2013). For Datta et al. (2015), intangible heritage site ecologies are intangible manifestations of history and culture via dance, song, art style, audio-visual presentations, among others. According to Cominelli and Greffe (2012), intangible cultural heritage has two relevant dimensions: the technical dimension, which integrates intangible cultural heritage know-how and experiences leading to its present day understanding, and the social dimension that is related to a dynamic view of knowledge in a context where agents interact in a social ecosystem and evolve.

A turning point in the analysis of intangible cultural heritage, and probably its inception into an integrated, modern view, was the Convention for the Safeguarding of the Intangible Cultural Heritage organized by UNESCO held in Paris in 2003. After preliminary efforts to protect folklore (Aikawa, 2004), the ensuing discussion and the resulting text of that Convention (i.e., UNESCO, 2003) are considered by many the central element of the recent interest in this kind of heritage.

Intangible cultural heritage can have solid characteristics in order to become central attractions for many segments of tourists. The quest for experiences and the search for knowledge of distant or different realities can be the basis for making the decision of visiting a space with a perceived valuable intangible cultural heritage, though some other drivers such as status, evasion, etc. can 
kao što su status, evazija, itd. Gubitak raznolikosti i kulturnog identiteta u nekim turističkim destinacijama zbog masovne proizvodnje turističkih doživljaja i standardizacije načina rada mnogih poduzeća također ističu vrijednost osobitih ili autentičnih trenutaka slobodnog vremena u kojima se upoznaje i uživa u nematerijalnoj kulturnoj baštini.

Pojam turizma baštine podrazumijeva „,vezu između očuvanja prošlosti zbog svoje intrinzične vrijednosti, ali i resurs za komercijalne djelatnosti suvremene zajednice“ (Ashworth i Tunbridge, 1990:24). Ideja održivog razvoja postaje središnji fokus diskusija o ovom obliku turizma, uglavnom zbog svoje krhkosti i zabrinutosti za očuvanje u budućnosti. Zapravo mnogi autori i stručnjaci u području kulture zagovaraju kontrolirani, dugoročni razvoj područja u kojima se ove nematerijalne prakse događaju kao sredstvo osiguranja preživljavanja i zaštite. Međutim, govoreći o njezinoj ekonomskoj koristi, Pfeilstetter (2015) upozorava da kultura postaje roba, naročito nakon što se obradi kao „baština“. Pereira Roders i van Oers (2011) tvrde da su nematerijalna kulturna baština i njezin odnos s održivim razvojem uvelike neistraženo područje.

Kad kulturna baština postane temom rasprave o održivom razvoju turizma, uvijek prevlada ekonomska vrijednost. Često se njezina vrijednost ne mjeri sa stanovišta održivosti, nego se smatra dijelom komercijalnog turističkog paketa nekog prostora. Gledano s tog stanovišta, njezina zaštita nije zagarantirana, nego postaje predmet hira komercijalnih interesa. Međutim, kao što naglašava Gartner (2014), mjerenje održivog razvoja destinacije zapravo pomiče vrijednost marke u domenu održivog razvoja zajednice, a time se ova dva koncepta spajaju u jednu cjelinu. Kulturna baština tako bi se mogla smatrati komercijalnim subjektom nastalim iz društvene snage koja omogućuje njezino istovremeno korištenje kao turističke atrakcije i kao integralnog elementa života zajednice. be present as well. The loss of diversity and cultural identity in some tourism destinations due to mass production of tourism experiences and standardization of operations by many firms also highlights the value of special or authentic leisure moments getting to know and enjoying intangible cultural heritage.

Heritage tourism refers to the 'the link between the preservation of the past for its intrinsic value, and as a resource for the modern community as a commercial activity' (Ashworth and Tunbridge, 1990:24). The idea of sustainable development becomes a central focus in the forum where this kind of tourism is discussed, mainly linked to its fragility and concern for future preservation. In fact, many authors and experts from the cultural field advocate for a controlled, long-term development of the territories where these intangible practices take place as a means of assuring survival and protection. However, referring to its economic use, Pfeilstetter (2015) indicates that culture is a commodity especially after being processed as 'heritage'. For Pereira Roders and van Oers (2011), intangible cultural heritage and its relationship with sustainable development is a largely unexplored territory.

When cultural heritage becomes part of the sustainable tourism development debate, it typically takes the form of an economic value. Often its value is not measured from the standpoint of sustainability but assumed to be part of the commercial tourism package of an area. When viewed this way its protection is not guaranteed but rather subject to the whims of commercial interests. However, as Gartner (2014) points out actually measuring sustainable destination development moves brand equity into the realm of sustainable community development and thus merges these two concepts into a unified whole. Cultural heritage would then be considered a commercial entity that arises from a social force that provides both for use as a tourism attraction and as an integral element of the life of the community. 


\section{KONKURENTNOST I ZNANJE U DESTINACIJAMA NEMATERIJALNE KULTURNE BAŠTINE}

Sa stanovišta javnih politika baziranima na turizmu, destinacije su osnovne jedinice kojima treba upravljati s ciljem održivog razvoja. Resursi i atrakcije destinacija mogu biti vrlo raznoliki i različito djelovati kao čimbenici privlačenja. Nematerijalni elementi, poput vrijednosti, znanja, itd., također se mogu percipirati kao resursi te tako postati dijelom nematerijalne kulturne baštine nekog kraja. U nekim destinacijama resursi poput „ozračja zabave“, sportske aktivnosti ili opuštenog načina života nisu samo elementi privlačenja turista nego su postali i glavnim razlozima njihovog dolaska. Tako su mnoga područja ili mjesta postala relevantna zahvaljujući nematerijalnoj baštini (Kaufmann, 2013), a neki atributi destinacija duboko su ukorijenjeni u vrijednostima, glazbi, običajima, itd. zajednica koje organiziraju turističke aktivnosti, a koje ta mjesta čine jedinstvenim.

Mnoge destinacije žestoko se natječu u privlačenju i zadržavanju turista. Budući da je turizam glavna gospodarska aktivnost mnogih ekonomija, a ovisnost o rentama koje generira je visoka, upravljanje turizmom na vrhu je prioriteta mnogih regija i zemalja. Uspjeh turističkih destinacija na mnogim tržištima ovisi o njihovoj relativnoj konkurentnosti (Enright i Newton, 2004; Mosammam, Sarrafi i Nia, 2019). Mnogi autori dali su svoj doprinos $\mathrm{u}$ raspravi o načinima postizanja konkurentnosti, a rastom broja radova u literaturi tema konkurentnosti destinacije postaje glavnom u području turizma.

Enright i Newton (2004) definiraju konkurentnost destinacije kao razinu do koje neka destinacija može privući i zadovoljiti potencijalne turiste. Pike (2008) vidi iz druge perspektive ovaj pojam pokušavajući povezati željene ishode s dionicima u stanju ravnoteže između stvarnog tržišnog stanja,

\section{COMPETITIVENESS AND KNOWLEDGE IN INTANGIBLE CULTURAL HERITAGE DESTINATIONS}

From a tourism-based public policy perspective, destinations are the main units to be managed with a sustainable development goal. Destinations have resources and attractions, which can be very diverse and act as pull-factors for tourists. Immaterial elements can be also seen as resources, such as values, knowledge, etc. and hence become part of the intangible cultural heritage nature of an area. In some destinations, resources such as the 'party atmosphere', sport activities or the relaxed way of life are not only attractors for tourists but also become the main reason for their trips. Thus, many regions or places owe their relevance to intangible heritage (Kaufmann, 2013) and some destination attributes are strongly rooted in values, music, customs, etc. of the communities which host the tourism activities and which make the area unique.

Many destinations compete hard to attract and retain tourists. As tourism is the main sector in many economies, and dependence on rents generated in this industry is high, managing the tourism sector is a top priority for many regions and countries. The success of tourism destinations in many markets depends on their relative competitiveness (Enright and Newton, 2004; Mosammam, Sarrafi and Nia, 2019). Many authors have contributed to the debate on how to achieve competitiveness and the number of studies in the tourism literature about destination competitiveness is growing, becoming a major topic in the field.

Enright and Newton (2004) define destination competitiveness as the degree to which a destination can attract and satisfy potential tourists. Pike (2008) adopts a different perspective to view the concept by trying to link desired outcomes to stakeholders under a situation of equilibrium. This author 
profitabilnih turističkih poduzeća, privlačnog okoliša, pozitivnih doživljaja posjetitelja i lokalnog stanovništva koje podupire razvoj turizma.

Nematerijalna kulturna baština ima jaku komponentu znanja. Taj se koncept može analizirati iz različitih perspektiva: stanje svijesti, objekt, proces, mogućnost pristupa informacijama ili sposobnost (Alavi i Leidner, 2001). Radnu definiciju daju Leonard i Sensiper (1998) interpretirajući znanje kao informaciju koja je relevantna, primjenjiva i barem djelomično temeljena na iskustvu. Znanje posjeduju pojedinci, ali također postoji i organizacijsko ili grupno znanje. To kolektivno znanje temelji se na zajedničkim idejama, modelima, rutinama $\mathrm{i}$ iskustvima.

U posljednjih nekoliko desetljeća, stajalište temeljeno na znanju konsolidiralo se $u$ okvir objašnjavanja i predviđanja u području menadžmenta. Usvajanjem stajališta temeljenog na znanju kao teorije strategije, znanje se konceptualiza kao resurs koji se može steći, transferirati ili integrirati kako bi se postigle stalne konkurentske prednosti (Eisenhardt i Santos, 2002). U tom smislu, znanje se smatra strateški najznačajnijim resursom (Grant, 1996).

Prema definicijama autora nematerijalne kulturne baštine (Cominelli i Greffe, 2012; Pereira Roders i van Oers, 2011), konceptualna sličnost sa znanjem temeljenom na organizaciji je visoka. To je rezultat interakcije ljudskog stvaralaštva s djelovanjem koje vodi stvaranju korisnosti. Alberti i Giuti (2012) u analizi kulturne baštine prema stajalištu temeljenom na znanju govore o usklađenosti između kulturne baštine i paradigme ,ekonomije znanja".

U posljednje vrijeme u kulturi se dogodio pomak usmjerenja s pristupa pukog očuvanja k perspektivi temeljenoj na ekonomskom unaprjeđenju (Lazzeretti, Capone i Cinti, 2011) i tako konkurentnost postaje potreba $u$ mnogim regijama u kojima se želi iskoristiti addresses destination competitiveness as a balance between an effective market position, profitable tourism businesses, an attractive environment, positive visitor experiences and supportive local residents.

Intangible cultural heritage has a strong knowledge component. The concept of knowledge can be analyzed from several perspectives: a state of mind, an object, a process, a condition of having access to information, or a capability (Alavi and Leidner, 2001). A working definition is provided by Leonard and Sensiper (1998) who view knowledge as information that is relevant, applicable and at least partly based on experience. Knowledge is held by individuals, but is also possible to refer to organizational or group knowledge. Shared ideas, frameworks, routines and joint experiences are the basis for that collective knowledge.

During the last decades, the knowledge-based view has been consolidating as an explanatory and predictive framework in the management field. When the knowledge-based view is adopted as a theory of strategy, knowledge is conceptualized as a resource that can be acquired, transferred, or integrated to achieve sustained competitive advantages (Eisenhardt and Santos, 2002). In this regard, knowledge is seen as the most strategically significant resource (Grant, 1996).

As Cominelli and Greffe's (2012) and Pereira Roders and van Oers's (2011) definitions of intangible cultural heritage show, the conceptual similarity with organization-based knowledge is high. It is the result of human creation coupled with action, thus leading to utility generation. Alberti and Giuti (2012) lay the foundation of the analysis of cultural heritage under the knowledge-based view when they refer to the fit between cultural heritage and the 'knowledge economy' paradigm.

In recent times culture has experienced a shift of focus going from a mere preservation approach towards a perspective based on its economic enhancement (Lazzeretti, Capone and Cinti, 2011), so competitiveness becomes 
to znanje na održiv način. Najvažnije je stvoriti konkurentske prednosti iz tog znanja. U svojoj analizi Blake (2014) tvrdi da je potencijalni doprinos nematerijalne kulturne baštine lokalnim ekonomijama već prepoznat kod donošenja politika u mnogim zemljama. Područja koja ova autorica izričito dokumentira su obrti i turizam. Baštinski lokaliteti oslanjaju se na naglašavanje razmišljanja i artikulacije turista integrirajući nematerijalne elemente u materijalni okoliš kao dijela očekivanog doživljaja turista (Datta et al. 2015). Dakako, veza između ekologije baštine i lojalnosti turizma temeljena na očekivanjima i namjerama nije jasna (Nasser, 2003; Datta et al. 2015).

Iz organizacijske perspektive, Grant (2002) predstavlja opći model kako bi procijenio potencijal resursa i sposobnosti za stvaranje profita. Ovaj model može se smatrati kao pokušaj za razvoj konkurentnosti budući da je u njegovoj srži stvaranje i održivost konkurentskih prednosti. U tom modelu Grant (2002) se osvrće na tri opća aspekta: obim uspostavljene konkurentske prednosti, održivost konkurentske prednosti i prisvojivost rente. Iako je Grantov model (2002) čvrsto ukorijenjen $u$ organizacijskim resursima i sposobnostima u poslovnom kontekstu, njegovi modeli mogu se primijeniti na destinaciju iz perspektive turizma. Elementi nematerijalne kulturne baštine čvrsto su ukorijenjeni u zemlje i zajednice te predstavljaju kritične čimbenike za stvaranje globalnih i konkurentskih scenarija (Cominelli i Greffe, 2012). Kultura se koristi u stvaranju novih industrija i radnih mjesta te doprinosi rješavanju socijalnih problema i onih u okolišu (Sasaki, 2010). Štoviše, regije mogu graditi svoju konkurentnost koristeći svoju kulturnu baštinu kao polugu (npr. Alberti i Giusti, 2012). K tomu, upravljanje kulturnom baštinom u destinaciji može pozitivno utjecati na održivi razvoj okoliša ljudi, a što zauzvrat može stimulirati i potaknuti održivi razvoj imovine kulturne baštine (Pereira Roders i van Oers, 2011). Jedan od pozitivnih učinaka a need for many regions that want to exploit this knowledge in a sustainable way. The key is to create competitive advantages from that knowledge. In her analysis, Blake (2014) posits that the potential contribution of intangible cultural heritage to local economies is already recognized in policymaking in many countries. The areas that this author explicitly documents are handicrafts and tourism. Heritage sites rely on accentuating the reflection and articulation of tourists by integrating intangibles in the tangible environment as a part of the tourist's experience calculus (Datta et al. 2015). However, the link between heritage ecology and tourism loyalty based on expectations and intentions is not clear (Nasser, 2003; Datta et al. 2015).

From an organizational perspective, Grant (2002) presents a general model to appraise the profit-earning potential of resources and capabilities. This model can be considered as an effort for the development of competitiveness since the creation and sustainability of competitive advantages lies at its core. In the model Grant (2002) pays attention to three general aspects: the extent of the competitive advantage established, the sustainability of the competitive advantage, and the rent appropriability. Though Grant's model (2002) is strongly rooted in organizational resources and capabilities in a business context, its elements can be applied to a destination from a tourism perspective. Intangible cultural heritage elements are deeply rooted in territories and communities and represent critical factors for creating new global and competitive scenarios (Cominelli and Greffe, 2012). Culture has been used in the creation of new industries and jobs and it has contributed to solving social and environmental problems (Sasaki, 2010). Moreover, regions may build their competitiveness by leveraging their cultural heritage (e.g., Alberti and Giusti, 2012). In addition, proper management of cultural heritage at a destination can play a positive role in the sustainable development of the human environment, which in return can stim- 
provedbe nacionalnih mjera zaštite naglašava se u UNESCO-voj Konvenciji o zaštiti nematerijalne kulturne baštine gdje se predlaže snažnije angažiranje kulturnih zajednica u upravljanje nematerijalnom kulturnom baštinom (Blake, 2014). Ipak, napredak modela i okvira upravljanja za postizanje tog cilja je neznatan.

Zbog posebnih značajki tog resursa i promjene u razini analize od poduzeća na područja, gradove, zemlje ili skupinu zemalja, potrebne su promjene kako bi se ponudio realističan model. U sljedećem odlomku razmatrat će se percipirana kvaliteta nematerijalne kulturne baštine, osiguranje njezine dugoročne stabilnosti i njezin potencijal generiranja rente s ciljem izgradnje valjanog modela u tom kontekstu. Jedini prethodni rad u literaturi je onaj autora Boude Figueredo i Luna (2013) koji su razvili sustav upravljanja znanjem iz leksikografske perspektive s ciljem zaštite nematerijalne kulturne baštine kolumbijskog karnevala Barranquilla čija lingvistička podloga služi za stvaranje interaktivnog repozitorija znanja.

\section{PERCIPIRANA KVALITETA NEMATERIJALNE BAŠTINE ZA KREIRANJE KONKURENTSKE PREDNOSTI}

Kako bi ustanovio konkurentsku prednost resursa, Grant (2002) spominje dva osnovna aspekta: oskudnost i relevantnost. U nastavku se razmatraju ova dva aspekta $u$ kontekstu nematerijalne kulturne baštine.

\subsection{Oskudnost}

Oskudica resursa povezana je s problemima analiziranim u ranijim radovima ekonomista. Pristup u teoriji strategije nudi ulate and foster the sustainable development of cultural heritage assets (Pereira Roders and van Oers, 2011). One of the positive effects of the application of national safeguarding measures by countries is emphasized in the UNESCO Convention for the Safeguarding of the Intangible Cultural Heritage. Here it is argued that cultural communities will become more closely involved in managing intangible cultural heritage (Blake, 2014). Nevertheless, the advances in management models and frameworks to achieve that goal are scarce.

Due to the specific characteristics of that resource and the change in the level of analysis from firms to regions, cities, countries or group of countries, some adaptations must be done to provide a realistic model. In the next section we discuss the perceived quality of the intangible cultural heritage, the assurance of its longterm sustainability, and its rent generation potential to build up a valid model in this context. The only direct antecedent found in the literature is the work by Boude Figueredo and Luna (2013), who develop a knowledge management system from a lexicographical perspective to safeguard intangible cultural heritage applied to the Carnival of Barranquilla (Colombia), with a linguistic background and to create an interactive knowledge repository.

\section{THE PERCEIVED QUALITY OF INTANGIBLE HERITAGE TO CREATE COMPETITIVE ADVANTAGES}

Grant (2002) addresses two basic aspects to establish a competitive advantage from a resource: scarcity and relevance. Next, those two aspects are discussed in the context of intangible cultural heritage.

\subsection{Scarcity}

Earlier works by economists have dealt with the problems linked to resource scarcity. The approach in the theory of strategy 
drugačiju perspektivu: jedinstveni resursi koji nisu pod kontrolom svih tvrtki u nekoj industriji mogu se koristiti kako bi se ponudili jedinstveni proizvodi ili provodili jedinstveni procesi. Kad se ta ideja prenese na polje destinacije, oskudno nematerijalno znanje može postati temeljem turističke ponude nečeg jedinstvenog u svijetu. Del Barrio, Devesa i Herrero (2012) navode novonastala područja i niše povezane $\mathrm{s}$ aspektima nematerijalne prirode na sve više segmentiranom tržištu koje nudi sve različitije kulturne proizvode. Posjetitelji koji žele doživjeti i osjetiti to nematerijalno znanje moraju posjetiti tu destinaciju jer ga ne mogu naći na drugim destinacijama. $S$ tog gledišta Pfeilstetter (2015) ukazuje da se doživljaji, proizvodi i usluge mogu konvertirati u tradicionalne i autentične, a time i poželjne, proizvode i usluge kad se dovedu u vezu s oskudnom i ekskluzivnom naslijeđenom prošlošću usađenom u nematerijalnu kulturnu baštinu.

Mnoge vrste znanja u destinaciji mogu biti temelj za postizanje konkurentske prednosti. Koncept nematerijalne kulturne baštine može uključiti osobitost određene skupine ili zajednice ljudi (Del Barrio, Devesa i Herrero, 2012). Standardni pokazatelj za analizu oskudnosti nematerijalne kulturne baštine i njezino uvrštavanje u UNESCO-ov Reprezentativni popis nematerijalne kulturne baštine čovječanstva kojim se obuhvaćaju oni elementi nematerijalne baštine kojima se pokazuje diverzije ove baštine i podiže svijest o njezinom značaju (UNESCO, 2003).

Međutim, popisivanje baštine može značiti uvrštavanje i izuzimanje, a što se često temelji na političkim izborima i potencijalu upravljanja (Eoin i King, 2013). Također je važno navesti da čak i kad se na UNESCO-v Reprezentativni popis ne upiše inherentno znanje nematerijalne kulturne baštine, ako je ta baština ekskluzivna, ipak može biti temelj za konkurentsku prednost u destinaciji, i obrnuto: sama činjenica da je nematerijalna kulturna baština na UNESCO-vom popisu takes a different perspective: unique resources which are not controlled by all the firms in an industry can be exploited to offer unique products or to conduct unique processes. Taking that idea to the destination field, scarce, intangible knowledge can be the basis to offer something unique in the world for tourists. According to Del Barrio, Devesa and Herrero (2012) new areas and niches have emerged associated with aspects of an intangible nature in an increasingly segmented market in which ever more diverse cultural products are to be found. Those visitors who want to experience and feel that intangible knowledge have to visit that destination, because they cannot find it in other destinations. Pfeilstetter (2015) adopts this perspective when he indicates that experiences, products and services can be converted into traditional and authentic products and services, and therefore desirable, when they relate to the scarce and exclusive inherited past that is embedded in intangible cultural heritage.

Many kinds of knowledge at a destination can be the basis to obtain competitive advantages. The concept of intangible cultural heritage is able to include the idiosyncrasy of a particular group or community of people (Del Barrio, Devesa and Herrero, 2012). The standard indicator to analyze the scarcity of intangible cultural heritage is its inclusion on the Representative List of the Intangible Cultural Heritage of Humanity by UNESCO, which encompasses those intangible heritage elements that help demonstrate the diversity of this heritage and raise awareness about its importance (UNESCO, 2003).

However, listing heritage can imply inclusion and exclusion, often based in political choices and management potential (Eoin and King, 2013). It is also important to outline that even when underlying knowledge of intangible cultural heritage is not inscribed on the Representative List of UNESCO, if that heritage is exclusive, it can still be the basis for competitive advantage at the destination, and vice versa: UNESCO-inscribed intangi- 
nije uvijek mogla biti relevantna za generiranje konkurentske prednosti. Stoga je potrebno analizirati relevantnost kao drugi ključni aspekt.

\subsection{Relevantnost}

Druga značajka kojom potencijal nematerijalne kulturne baštine kao dragocjeno znanje dobiva konkurentsku prednost u destinaciji jest relevantnost. Popisivanje baštine podrazumijeva percepciju značaja (Eoin i King, 2013), ali postoje mnogi drugi oblici nematerijalnog znanja koji mogu biti relevantni nekim segmentima turista. Vjerojatno je ključ procjene relevantnosti nematerijalne kulturne baštine imidž toga znanja. Kao što su naglasili Datta et al. (2015), najvažnije je stvoriti opći turistički imidž koji je u skladu s očekivanjima od tog baštinskog lokaliteta.

Imidž je ključna sastavnica u stvaranju relevantnosti destinacija i njihovih nematerijalnih baštinskih proizvoda. Važan je i za odlučivanje o vrstama aktivnosti koje će se provoditi i nuditi u destinaciji. Kako je osobni imidž nekog mjesta osobna stvarnost, a ta stvarnost se razlikuje od osobe do osobe, važno je razumjeti kako se imidži projiciraju, primaju i asimiliraju. Stotine članaka napisano je o pojmu imidža u području razvoja turizma (npr. Pike, 2002). U jednom od tih radova Gartner (1993) izdvaja osam pokretača na kontinuumu, od induciranih imidža nastalih pod utjecajem vanjskih sila do organskih imidža koji se zasnivaju na posjetima. Zbog sve veće uporabe društvenih medija čini se da je prodor na tržište organskih pokretača, koji se već i smatraju vjerodostojnijima od induciranih, sve intenzivniji. Praćenjem stranica društvenih medija menadžeri i dionici u destinacijama mogu ocjenjivati reakcije tržišta na materijalnu i nematerijalnu ponudu na razini nasumičnih priča u destinaciji.

Imidž ima potencijal modifikacije bilo kojeg proizvoda nematerijalne ili materijalne kulturne baštine u nekoj destinaciji. Atrak- ble cultural heritage knowledge could not be always adequate for generating competitive advantage. In that sense, relevance is another key aspect to analyze.

\subsection{Relevance}

The other characteristic that sets the potential of intangible culture heritage as valuable knowledge to establish a competitive advantage in the destination is relevance. Listing heritage implies a perception of significance (Eoin and King, 2013), but there are many other forms of intangible knowledge which can be relevant for some segments of tourists. Probably, the key to considering intangible cultural heritage as relevant is the image held of that knowledge. As Datta et al. (2015) posit, creating a public tourist image in line with heritage site expectations is paramount.

Image is a key component in creating relevance for destinations and their intangible heritage products. It is also instrumental in determining the type of activities that will be undertaken and provided within a destination. Since a person's image of a place is their reality and that reality differs from person to person it is important to understand how images are projected, received and assimilated. Hundreds of articles have been written on the concept of image in the tourism development field (e.g., Pike, 2002). In one of those works, Gartner (1993) identifies eight image formation agents that appear along a continuum from induced, images that external forces try to create, to organic, images that are based on visitation. With the increasing use of social media, it appears the organic image formation agents, which are already viewed as more credible than the induced forms, are increasing their market penetration. Monitoring social media sites allows destination managers and stakeholders to anecdotally assess market response to tangible and intangible heritage offerings at destinations.

Image has the potential to modify any intangible or tangible cultural heritage prod- 
cije nematerijalne kulturne baštine podložne su većoj manipulaciji imidža jer se oslanjaju na osjećaje i emocije za razliku od onih u fizičkom obliku. U činjenici da se nematerijalna kulturna baština može interpretirati na različite načine leži najveća prilika za utjecaj imidža i pokretače formiranja imidža na način viđenja, baratanja i oblikovanja materijalne i nematerijalne kulture $\mathrm{u}$ atrakcije. Kako je valorizacija imidža obično anegdotalne prirode, njegovo mjerenje mora se odmaknuti dalje u domenu stvarnog mjerenja $u$ novčanim iznosima. To je moguće jer postoje alati i informacije za provođenje takvog postupka (Gartner, 2014).

\section{ODRŽIVOST KONKURENTSKE PREDNOSTI DESTINACIJA TEMELJENIH NA NEMATERIJALNOJ BAŠTINI}

Nakon što destinacija počne koristiti konkurentsku prednost temeljenu na oskudnosti i relevantnosti svoje nematerijalne kulturne baštine, javlja se neizvjesnost duljine trajanja te prednosti. Time se povećava bojazan o održivosti njezine konkurentske prednosti, kako zbog dugoročnog preživljavljavanja tako i zbog jedinstvenosti u odnosu na konkurenciju. Tri su ključna aspekta održivosti dragocjene nematerijalne kulturne baštine: autentičnost usađena $\mathrm{u}$ mjestu, kratkoročna zaštita i prijenos međugeneracijskog znanja.

\subsection{Autentičnost usađena u mjestu}

Konkurenti u nekoj destinaciji mogu pokušati slomiti konkurentnu prednost temeljenu na znanju na dva uobičajena načina, a ta su preuzimanje znanja koje polučuje vrhunske rezultate ili vlastiti razvoj tog znanja (Grant i Jordan, 2012). Stoga su međudestinacijska prenosivost znanja i mogućnost repliciranja znanja dvije glavne prijetnje u potkopavanju uct a destination provides. Intangible cultural heritage attractions are prone to more image manipulation as they rely on feelings and emotions rather than something with physical form. Intangible cultural heritage is open to interpretation and this is where image and image formation agents have the most opportunity to affect how tangible and intangible culture are viewed, manipulated and formed into attractions. As image is usually assessed in an anecdotal manner, its future measurement must move beyond the anecdotal realm into that of real measurement in monetary terms. As Gartner (2014) argues, it is possible to do that as the tools and information to guide the process exist.

\section{SUSTAINABILITY OF THE COMPETITIVE ADVANTAGE FOR INTANGIBLE DESTINATIONS}

Once a destination enjoys the benefits of a competitive advantage based on the scarcity and relevance of its intangible cultural heritage, the uncertainty about the time length of that advantage is present. That raises the concern about the sustainability of the competitive advantage, both in terms of its survival in the long term and the uniqueness that it presents regarding competitors. Three aspects are identified as key in the sustainability of valuable intangible cultural heritage: place-embedded authenticity, short-term safeguarding, and inter-generational knowledge transfer.

\subsection{Place-embedded authenticity}

If competitors attempt to destroy a destination's knowledge-based competitive advantage, two traditional ways to do it are the acquisition of the knowledge that underpins the superior performance or the internal development of that knowledge (Grant and Jordan, 2012). Thus, inter-destination transferability of knowledge and knowledge repli- 
konkurentske prednosti destinacija nematerijalne baštine. S druge strane, ako nematerijalnu baštinu u destinaciji obilježava u mjestu usađena autentičnost, tada prenosivost i mogućnost repliciranja od strane konkurenata postaje vrlo malo vjerojatna.

Autentičnost se pomno analizirala u turističkoj literaturi. MacCannell (1973) tvrdi da turiste motivira želja da vide kako se stvarno živi u mjestima koje posjećuju. Autentičnost u području turizma često se opisuje atributima poput ,stvaran, pouzdan, vjerodostojan, originalan, neposredan, suštinski istinit i prototipski za razliku od kopiranog, reproduciranog ili vjerne kopije originala" (Ram, Björk i Weidenfeld, 2016:110).

Fu, Kim i Zhou (2015) upozoravaju na osporavanje konvencionalne ideje autentičnosti u turističkim znanstvenim člancima u kojima autori naglašavaju da svi turistički doživljaji ne zahtijevaju obaveznu usađenost objektivne autentičnosti u umjetničke artefakte, predmete ili čak situacije. Tako bi imitacija nematerijalne baštine u drugim destinacijama mogla predstavljati prijetnju originalnim destinacijama zbog mogućeg gubitka konkurentske prednosti ako se autentičnost koju turisti traže ne temelji na objektivnim parametrima ili ako se značajke znanja inherentnog nematerijalnoj baštini mogu replicirati bez gubitka originalnosti vezane za izvorno geografsko mjesto. Repliciranje znanja izvan zajednice koja ga je stvorila je teško, a još veći izazov predstavlja za muzeje i konzervatorske institucije (Kurin, 2004). No, u vremenu rastuće digitalne evolucije i uz raširene, jake mogućnosti geografske mobilnosti ljudi u svrhu relokacije u različite destinacije gdje se to znanje također može pokrenuti, odabir ponovnog stvaranja znanja u novom okolišu može se izvesti u nekim elementima nematerijalne baštine. Neke druge destinacije bi mogle pokušati imitirati $i$, uvesti“ relevantne elemente nematerijalne baštine zbog njezine egzotičnosti, relevantnosti ili prestiža - poput Las Vegasa. cability are two major threats that can erode the competitive advantage of intangible heritage destinations. However, if the destination's intangible heritage is characterized by place-embedded authenticity, then transferability and replicability by competitors become highly unlikely.

Authenticity has been deeply analyzed in the tourism literature. According to MacCannell (1973), tourists are motivated by a desire to see life in the places they visit as it is really lived. Authenticity in the tourism field is often linked to "real, reliable, trustworthy, original, first hand, true in substance, and prototypical as opposed to copied, reproduced or done the same way as an original" (Ram, Björk and Weidenfeld, 2016:110).

For Fu, Kim and Zhou (2015), the conventional notion of authenticity has been challenged by tourism scholars who highlight that not all touristic experiences require an objective authenticity embodied in the toured artefacts, objects or even situations. Thus, the imitation of intangible heritage in other destinations could be a threat for the original destination which could lose its competitive advantage if the authenticity required by the tourist is not based in objective parameters or if the characteristics of the knowledge underlying the intangible heritage can be replicated without losing the originality associated to the geographical place of origin. Knowledge replication outside the community that has created it is difficult, and it is even a challenge for museums and preservation institutions (Kurin, 2004). But in an era of increasing digital evolution and with widespread though country-dependent possibilities of people's geographical mobility for relocation in different destinations where this knowledge can be also put into motion, the option of recreating the knowledge in a new environment can be feasible for certain elements of intangible heritage. Some other destinations could attempt to imitate and 'import' relevant elements of the intangible heritage due to its exoticism, relevance, or prestige, in a Las Vegas-fashion. 
Ključ održavanja konkurentske prednosti u tom smislu leži u čvrstoj vezi između autentičnosti i konteksta gdje se znanje o nematerijalnoj baštini kreira i razvija. Ograničavanje pokušaja imitacije može se temeljiti na subjektivnoj percepciji turista o zahtjevima autentične prirode znanja i poveznice do određenog konteksta gdje je to znanje izvorno postalo relevantno. Stoga, što je jača veza nematerijalnog znanja $\mathrm{s}$ materijalnim prostorom u kojem koegzistira, to je destinacija zaštićenija od prijetnji drugih koje žele ponuditi istu ili sličnu nematerijalnu baštinu kao jednu od atrakcija u svojoj strategiji. González (2008) navodi da se nematerijalna baština može reproducirati u drugim zemljama za egzistencijalne turiste koji žele integrirati daleku kulturu u svoj vlastiti identitet. Međutim, većinu dokonih turista ne zanima „transportirana“ atrakcija jer, čini se, gubi šarm čim se izmjesti iz svojeg izvornog lokaliteta (González, 2008). Intenzitet potrage za autentičnošću i poveznica s geografskim područjem mora dovesti autentičnu destinaciju u prednost da bi nadvladala potencijalnu ponudu pristupačnijih, udobnijih pa čak i jeftinijih alternativnih destinacija koje još možda nude i dodatne turističke atrakcije zbog kojih su vrlo konkurentne.

\subsection{Kratkoročna zaštita}

Disciplina očuvanja baštine formirala se u prvim desetljećima devetnaestog stoljeća, a glavni aspekt koncepta bila je autentičnost (Poulios, 2010). Suočena s promjenama i evolucijom ,modernog života“, prošlost se promatrala s nostalgijom i dobila je veliku vrijednost. Iako se uobičajeno nastoji očuvati fizičke baštine i spomenike (Condominas, 2004; Poulios, 2010), relevantnost nematerijalne baštine posljednjih je godina polučila čvrste razlo-
The key to sustain the competitive advantage in this regard lies in the strong link between authenticity and the context where the knowledge about the intangible heritage was created and developed. The barriers to imitation initiatives can be based on the tourist's subjective perception about the requirements of the authentic nature of the knowledge and the links to the specific context where this knowledge originally became relevant. Thus, the stronger the association of the intangible knowledge with the tangible space where it has coexisted, the more protected the destination is in facing the threat of other destinations who would like to offer the same or similar intangible heritage as one of the attractions in their strategy. González (2008) indicates intangible heritage can be reproduced in other countries for existential tourists, who want to integrate a distant culture within his/her own personal identity. However, most leisure tourists have a lack of interest in the 'transported' attraction, as once removed from its original place it appears to lose its charm (González, 2008). The intensity of the quest for authenticity and its link with the geographical area must put the authentic destination in an advantageous position to overcome the potential offerings of more accessible, more comfortable, and even cheaper alternative destinations, perhaps with complementary tourism attractions which make them very competitive.

\subsection{Short-term protection}

In the first decades of the nineteenth century, the discipline of heritage conservation was formed and authenticity was a key aspect in the concept (Poulios, 2010). Facing the changes and the evolution of "modern life", the past was observed with nostalgia and was endowed with high value. Though the traditional goal is the preservation of the physical heritage and monuments (Condominas, 2004; Poulios, 2010), the relevance of intangible heritage in recent years has pro- 
ge za pozivanje na zaštitu i očuvanje ove vrste baštinskih resursa.

Analizom značenja i pristupa u radovima u literaturi na temu zaštite i očuvanja nematerijalne kulturne baštine mogu se utvrditi dvije perspektive ili dimenzije: kratkoročna perspektiva koja određuje održavanje i čistoću standarda i znanja koje definira nematerijalnu baštinu u sadašnjosti i bliskoj budućnosti; i dugoročnu perspektivu koja se odnosi na prijenos nematerijalnog znanja budućim generacijama. Te perspektive ističu različite aspekte i zahtijevaju različite teoretske okvire. Kratkoročna dimenzija uglavnom je povezana s kulturnom i motivacijskom dinamikom i tema je ovoga odlomka. Dugoročna perspektiva uglavnom zauzima stajalište transfera znanja i razmatra se u sljedećem odlomku. Iako ona također obuhvaća kulturne i motivacijske aspekte uz nekoliko dodatnih čimbenika transfera, njezina je vremenska analiza različita.

Čuvanje nematerijalne baštine bilo je zanemareno do 1980-ih godina (Condominas, 2004). Nasser (2003) piše kako tradicionalna povijesna mjesta prolaze $\mathrm{kroz}$ procese redefiniranja i reinterpretiranja kulturne baštine da bi postala konkurentna i atraktivna, ali kako na taj proces utječu komercijalne sile potražnje potrošača čime se u mnogim slučajevima ugrožava konzervacija i kulturne vrijednosti. Česti su slučajevi da resursi nematerijalne kulturne baštine $\mathrm{s}$ povijesnim, društvenim, ekonomskim i političkim vrijednostima nestaju ili su već nestali (Li, 2012). UNESCO daje popis nematerijalne kulturne baštine kojoj je potrebna hitna zaštita.

U okviru kratkoročne perspektive, jedna od najvažnijih opasnosti od koje treba zaštititi nematerijalnu baštinu su kulturne promjene. Sam i Berry (2010) definiraju akulturaciju kao proces kulturne i psihološke promjene koja se događa nakon susreta kultura. Turizam polaže temelje za akulturaciju zbog dolaska ljudi iz drugih regija/zemalja u destinacije s lokalnim zajednicama. U susretu duced a solid call for protection and safeguarding this kind of heritage resources.

After analyzing the meaning and approach of works on protection and safeguarding of intangible cultural heritage in the literature, two perspectives or dimensions can be identified: a short-term perspective which deals with the maintenance and purity of the standards and knowledge that define the intangible heritage in the present and near future; and a longterm perspective which is concerned with the transfer of the intangible knowledge to future generations. Those perspectives emphasize different aspects and call for different theoretical frameworks. The short-term dimension is mainly related to cultural and motivational dynamics and is addressed in this section; the long-term one mainly adopts a knowledge transfer view and is addressed in the following section, and though it also encompasses cultural and motivational aspects along with several additional transfer factors, its temporal analysis is different.

Safeguarding the intangible heritage had been neglected until the 1980s (Condominas, 2004). Nasser (2003) outlines that traditional historic places are undergoing a redefinition and reinterpretation of their cultural heritage in order to be competitive and attractive, but this process makes heritage places respond to the commercial forces of consumer demand, and in many cases conservation and cultural values are being compromised. In many cases intangible cultural heritage resources with historical, social, economic and political values are disappearing or have disappeared $(\mathrm{Li}$, 2012). UNESCO also lists intangible cultural heritage in need of urgent safeguarding.

Within a short term perspective, one of the most important dangers to safeguard intangible heritage refers to cultural changes. For Sam and Berry (2010), acculturation is the process of cultural and psychological change that results following the encounter of cultures. Tourism lays the basis for acculturation due to the arrival of people from other regions/countries into a destination 
ljudi s različitim kulturnim tradicijama oni se mogu (ili ne mogu) prilagoditi jedni drugima u smislu ponašanja, jezika, vjerovanja, vrijednosti, društvenih institucija i tehnologija (Sam i Berry, 2010). Neke kulture nerado usvajaju nova znanja ili predmete čije se kulturne vrijednosti smatraju oprečnima prema relevantnim, tradicionalnim aspektima njihovog načina života ili običajima. Iako ovo može vrijediti za lokalne zajednice s nematerijalnom kulturnom baštinom koja se smatra društveno relevantnom, u drugim slučajevima kulturni utjecaj turizma, medija, ili putovanja rezidenata $u$ druga područja mogu potaknuti promjene ili čak odustajanje od tih znanja i praksi. U analizi kulturnih učinaka turizma Besculides, Lee i McCormick (2002:307) navode da dok ,predstavljanje kulture turistima može pomoći očuvanju te kulture, ono ju također može razvodniti ili čak i uništiti““. Kulturna invazija izvana i/ili zagađenje koje značajno može promijeniti nematerijalne prakse, a potencijalna demotivacija lokalnog stanovništva da ih nastavi zbog vanjskih utjecaja, glavni su problemi ove perspektive.

Također je važno odgovarati na stalne promjene vrijednosti u odnosu na upravljanje kulturno značajnim mjestima (Vakhitova, 2015). Načela održivog razvoja mogu se primijeniti na upravljanje kulturnim resursima baštine i koristiti za osiguranje, bolju uporabu i razumijevanje baštine u okolišu, materijalnoj i nematerijalnoj baštini (Keitumetse, 2011). Očuvanje znanja nematerijalne baštine očekivano traži eklektičan pristup koji integrira relevantnost prošlosti i važnost osnovnih dionika koji zadržavaju baštinsko znanje integriranjem pristupa baziranim na vrijednostima i živućoj baštini.

Lokalne zajednice nositelji su tradicija i prakse te se percipiraju kao osnovni čuvari koji proizvode, održavaju i čuvaju baštinu (Vakhitova, 2015) jer je za očuvanje nematerijalne, žive kulture potrebna kontinuirana društvena praksa (Kurin, 2004). Duvelle with a local community. When people from different cultural backgrounds come into contact, they may (or may not) adopt each other's behaviors, languages, beliefs, values, social institutions, and technologies (Sam and Berry, 2010). Some group cultures are reluctant to integrate new knowledge or artefacts whose underlying cultural values are considered to clash with relevant, traditional aspects of their way of life or habits. Though this can be the case regarding local communities with intangible cultural heritage which has been socially considered relevant, in other cases the cultural impact of tourism, the media, or the residents' trips to other regions can unleash processes of alteration or even giving up intangible cultural heritage knowledge and practices. In their analysis of cultural effects caused by tourism, Besculides, Lee and McCormick (2002:307) indicate that while 'presenting a culture to tourists may help preserve the culture, it can also dilute or even destroy it'. External cultural invasion and/or contamination which significantly change the intangible practices, and the potential residents' demotivation to continue them caused by those cultural influences are the main problems in this perspective.

It is also important to respond to changing values over time in the management of culturally significant places (Vakhitova, 2015). The principles of sustainable development can be applied to cultural heritage resource management, and used to secure a better use and understanding of the heritage in the forms of environment, tangible and also intangible heritage (Keitumetse, 2011). Safeguarding intangible heritage knowledge probably calls for an eclectic approach that integrates the relevance of the past and the importance of the core stakeholders that retain the heritage knowledge by integrating the value-based and the living heritage approaches.

Local communities are the carriers of traditions and practices and they are seen as the essential guardians who produce, maintain and safeguard heritage (Vakhito- 
(2013) ukazuje na dugoročne politike i strategije nekih zemalja u cilju očuvanja nematerijalne kulturne baštine ili nacionalne zakonske i političke strategije integriranja kulture u sveobuhvatnije razvojne planove. Kao specifične mjere zaštite, države često pokreću akcije osvještavanja i informiranja, nacionalnih inventura, nominacija za međunarodne popise i suradnje s drugim zemljama gdje se razmjenjuje znanje uz pomoć UNESCO-ve konvencije (Duvelle, 2013). Digitalizacija je također česta metoda čuvanja nematerijalne baštine (npr. Chen, 2014), a uključuje skeniranje i transkripciju dokumenata te snimanje vizualnih i usmenih elemenata izvedbi i manifestacija. UNESCO također popisuje elemente nematerijalne kulturne baštine za koje je utvrđeno da su primjeri najbolje prakse njihova očuvanja.

Jedan oblik zaštite nematerijalne baštine može biti i obrana od konkurentskog oponašanja. Koriste se ograničenja stranim organizacijama i pojedincima u istraživanju nematerijalne kulturne baštine (Li, 2012) ili zakoni kojima se štite njezini posebni proizvodi (Zhou, 2014). Sljedeći pravac djelovanja su zakonski okviri kojima se regulira veza između nematerijalne kulturne baštine i zakona o intelektualnom vlasništvu, ali oni su osobito teško provedivi zbog kolektivne i vremenske prirode prava (npr. Li, 2012). Stoga su pitanja o pravima intelektualnog vlasništva važan dio UNESCO-vih rasprava o očuvanju kulture još od ranih 1950-ih (Duvelle, 2013).

\subsection{Prijenos znanja}

Jedan važan oblik održavanja konkurentske prednosti nematerijalne baštine je osiguranje prijenosa ključnog znanja na glavne va, 2015), since intangible, living culture is preserved through continuous social practice (Kurin, 2004). Duvelle (2013) indicates that some countries have adopted long-term policies and strategies for safeguarding intangible cultural heritage or have enacted a national legal and policy strategy for integrating culture into larger development agendas. As specific protection measures, countries usually engage in awareness-raising and information campaigns, national inventories, nominations for international lists, and cooperation through the mechanisms established by the UNESCO Convention with other countries where they exchange safeguarding knowledge (Duvelle, 2013). Digitalization is also a common method used to preserve intangible heritage (e.g., Chen, 2014), including the scanning and transcription of documents and the recording of visual and oral elements of performances and manifestations. UNESCO also lists elements of intangible cultural heritage identified as practicing best safeguarding practices.

The protection of the intangible heritage can also have a dimension regarding the construction of barriers to imitation by competitors. Restrictions to investigate intangible cultural heritage by foreign organizations and individuals (Li, 2012) or laws to protect specific outputs of intangible cultural heritage (Zhou, 2014) are used. Legal frameworks encompassing the link between intangible cultural heritage and intellectual property laws are another line of action, but their enactment and application are extremely difficult due to the collective and temporal nature of the rights (e.g., Li, 2012). In this sense, questions concerning intellectual property rights have been an important part of UNESCO's discussions on the conservation of culture since the early 1950s (Duvelle, 2013).

\subsection{Knowledge transfer}

A relevant aspect to sustain the competitive advantage achieved in an intangible heritage setting is to assure that key knowledge 
pokretače u destinaciji. Na taj način starije generacije koje imaju vezu ili znanje o određenoj baštini trebale bi prenositi to inherentno znanje mlađim generacijama. Transfer znanja nematerijalne baštine mora biti točan i pravovremen (Condominas, 2004).

Cooper (2006) tvrdi da je krajnji cilj modela upravljanja znanjem učinkovit prijenos i upotreba znanja koje doprinosi konkurentnosti. Prijenos znanja od iznimne je važnosti kod stajališta temeljenog na znanju. Uzimajući ideje iz područja organizacije, transfer znanja može se definirati kao proces kroz koji sudionici razmjenjuju, primaju i pod utjecajem su doživljaja i znanja drugih (Van Wijk, Jansen i Lyles, 2008). Koristan je koncept rada zajednica koji se temelji na osnovi etnografskih studija i primjene u organizacijama (Brown i Duguid, 1991), a uključuje ustrojene ili neformalne skupine pojedinaca koje se okupljaju oko neke djelatnosti druženjem stvaraju zajedničke identitete.

Većina nematerijalne kulturne baštine temelji se na tacitnom znanju, a njegovo prenošenje je polagano, skupo i nesigurno (Teece, 1981). Literatura o upravljanju znanjem često preporuča prijenos tacitnog znanja putem neposrednog druženja, bez šifriranja u dokumente, ekspertne sustave, itd. zbog minimiziranja gubitka znanja. Condominas (2004) navodi da nematerijalna kultura temeljena na usmenoj predaji, osim govora, sadrži i pokret, geste, vizualne znakove, melodije i rad na predmetima.

Cooper (2006) se osvrće na prijenos znanja na razini destinacije kao dijeljenje znanja širom mreže. Poseban kontekst nematerijalne baštine definira pokertače - članove obitelji, susjede, prijatelje i sumještane u prostoru gdje se znanje stvorilo i razvilo iz relevantnih elemenata mreže, često pod vodstvom kulturnih i regionalnih udruženja lokalnih političara i destinacijskih menadžera. Zapravo, jedan od razloga tako čvrste povezanosti s baštinom je čovjekova želja da ju predaje dalje svojim potomcima (Condominas, 2004). is passed on to key agents at the destination. Thus, older generations in contact with or knowledgeable about that heritage are supposed to transmit its underlying knowledge to younger generations. The transfer of the intangible heritage knowledge must be accurate and timely (Condominas, 2004).

Cooper (2006) states that an ultimate goal of a knowledge management model is the effective transfer and use of knowledge to contribute to competitiveness. Knowledge transfer is of paramount importance in the knowledge-based view. Taking ideas from the organizational field, knowledge transfer can be defined as the process through which actors exchange, receive and are influenced by the experience and knowledge of others (Van Wijk, Jansen and Lyles, 2008). With a base from ethnographic studies and an application in organizations, a useful concept is the communities of practice (Brown and Duguid, 1991), that are formal or informal groups of individuals with an activity context within which they interact and create shared identities.

Most intangible cultural heritage is based on tacit knowledge. The transfer of such knowledge is slow, costly and uncertain (Teece, 1981). The literature on knowledge management tends to recommend the transfer of tacit knowledge through 'face-to-face' interaction, without codifying it in documents, expert systems, etc. in order to minimize knowledge losses. Condominas (2004) defines intangible culture based on its oral transmission; it deals with speeches but also movements, gestures, visual signals, melodies, and working on objects.

Cooper (2006) addresses knowledge transfer at the destination level as knowledge sharing across a network. The specific context of intangible heritage defines the agents of that network - family members, neighbors, friends, and fellow residents in the area where the knowledge has been created and developed form the relevant elements of the network, often guided by leaders of cultural and regional associations, local politicians 
Najrasprostranjeniji oblici prenošenja znanja nematerijalne baštine su društveni događaji, obiteljsko prenošenje, mentoriranje, lokalna udruženja i, u zadnje vrijeme, školovanje i edukacije. Condominas (2004) bilježi druge tradicionalne metode prenošenja znanja u svojoj analizi griot-a, tj. narodnih pripovjedača, koje se uglavnom temelje na pamćenju i sposobnosti pričanja na zajedničkim večernjim druženjima. Literatura o prijenosu znanja od osnivača na nasljednike u obiteljskim tvrtkama ilustrira načine i izazove međugeneracijskog prijenosa znanja nematerijalne baštine.

Iako Cooper (2006) destinacijskim menadžerima savjetuje mapiranje, bilježenje i šifriranje znanja, Brown i Duguid (1991) upozoravaju da se učenje njeguje omogućavanjem pristupa i članstva u ciljanoj zajednici, a ne apstraktnim objašnjavanjem pojedinih običaja. Nematerijalna baština češće je usmena nego pisana (Condominas, 2004), a Grant (1996) ističe da upravo prepreke prenošenja i ponavljanja znanja omogućavaju stratešku važnost. Međutim, konkurentska perspektiva mogla bi se sukobiti sa zaštitom gore iznesenih interesa, što bi se moglo pokazati iznimno važnim za određenu nematerijalnu baštinu.

Prijenos znanja nailazi na mnoge prepreke. U kontekstu nematerijalne baštine, raspoloženje starijih generacija da prenose znanje prihvaća se kao činjenica. Ipak, motivacija mlade generacije nije posve jasna budući da moderan život i kulturne ideje mogu nuditi znanje koje nije baš tako zanimljivo mladim sumještanima pa bi ga oni mogli i odbaciti kao stare tradicije koje su u sukobu s njihovim idejama suvremenosti i napretka. Stoviše, zbog životnih stilova mladih generacija, također se mogu izgubiti glavni aspekti razumijevanja praksi i njihovih izvedbi, čime bi se stvorile prepreke uslijed niskog apsorpcijskog kapaciteta (npr. Volberda, Foss i Lyles, 2010). Migracije također mogu duboko utjecati na prijenos znanja, zbog napuštanja zemlje ili propuštanja prijenosa/primanja and destination managers. In fact, one of the reasons why people in a society are so attached to heritage is because they want to pass it on to their descendants (Condominas, 2004). Social events, transmission in the family, mentorship, local associations, and lately formal education or training are the most prevalent formats to transfer intangible heritage knowledge. Condominas (2004) documents other traditional methods of transfer in his analysis of griots or folk poets, which is mainly based on memory and the quality of the transmission in groups gathering together in the evening. The literature on knowledge transfer in family firms between the founder and the successor serves to illustrate the intergenerational transfer of intangible heritage knowledge and its challenges.

Though Cooper (2006) recommends destination managers to map, capture and codify knowledge, Brown and Duguid (1991) indicate that learning is fostered by granting access and membership to the target community of practice, not by explicating abstractions of individual practices. Intangible heritage is often oral rather than written (Condominas, 2004) and Grant (1996) points out that precisely the barriers to the transfer and replication of knowledge grant it strategic importance. However, the competitive perspective could clash with the protection interests explained above which can be paramount for certain intangible heritage.

Knowledge transfer encounters many barriers. In the context of intangible heritage, the older generation's disposition to pass the knowledge along is usually taken for granted. Nevertheless, the younger generation's motivation is not so clear, since life and cultural ideas from the modern world can render that knowledge not so interesting for young residents, who could even reject it on the basis of old traditions that clash with their ideas of modernity and progress. Moreover, the younger generation's modern lifestyles can also imply that key aspects to understand the practice and its performance 
dragocjenog znanja potencijalnih izvora ili primatelja znanja.

\section{GENERIRANJE RENTE I PRISVAJANJE OD STRANE ZAJEDNICE}

Stvaranje održivih konkurentskih prednosti podrazumijeva potencijal unaprjeđenja konkurentnosti destinacije i dobrobiti zajednice, osobito u njezinoj ekonomskoj dimenziji, kao što se navodi u istraživanjima o konkurentnosti turizma. U tom smislu, Enright i Newton (2004:778) tvrde da je destinacija konkurentna kad „može privući i zadovoljiti potencijalne turiste". Ta konkurentnost će polučiti kontinuirano privlačenje turista i njihovo zadovoljstvo uživanjem proizvoda nematerijalne kulturne baštine. Veće zadovoljstvo posjetitelja očituje se u potrošnji svakog turista (Croes i Kubickova, 2013). Štoviše, zadovoljstvo ima pozitivan utjecaj na naknadno ponašanje potrošača (Moreira i Iao, 2014). Ryglová et al. (2018) su empirijski utvrdili da u turizmu zadovoljstvo pozitivno utječe na lojalnost prema destinaciji. To je također i temelj za razvijanje lojalne baze posjetitelja koja je pod utjecajem očuvanja održivosti destinacije uz istovremeno korištenje nematerijalne kulturne baštine kao konkurentske prednosti. Moreira i Iao (2014) tvrde da nekoliko istraživanja pokazuje različite koristi koje se mogu dovesti u vezu s ponovnim dolascima turista u destinaciju, a to su pružanje stabilnog tržišta destinaciji i besplatno oglašavanje u obliku preporuka usmene predaje za članove obitelji i prijatelje. Ova situacija osigurava rentu, a priljev turista povećava lokalne prihode izravno (smještaj, hrana, piće, itd.) i neizravno. Prihod od turizma se uvećava, što je u skladu s mnogim modelima konkurentnosti destinacije koja vidi re- have been avoided, hence experiencing barriers due to a low absorptive capacity (e.g., Volberda, Foss and Lyles, 2010). Migration can also deeply affect knowledge transfer, since potential knowledge sources or recipients can leave the region and fail to transfer/ receive the valuable knowledge.

\section{RENT GENERATION AND APPROPRIATION BY THE COMMUNITY}

The creation of sustainable competitive advantages entails the potential of competitiveness improvements in the destination and the community's wellbeing, particularly in the economic dimension of this latter concept as research on tourism competitiveness has outlined. In that line, Enright and Newton (2004:778) state that a destination is competitive when "it can attract and satisfy potential tourists". That competitiveness will result in the continuous attraction of tourists and their satisfaction from consuming intangible cultural heritage products. Higher levels of visitors' satisfaction are revealed in spending per capita (Croes and Kubickova, 2013). Moreover, satisfaction has a positive impact on consumer post-purchase behavior (Moreira and Iao, 2014). In the tourism field, Ryglová et al. (2018) empirically find that satisfaction positively influences loyalty towards the destination. That is also the basis for developing a loyal visitor base which is affected by maintaining destination sustainability while at the same time using intangible cultural heritage for a competitive advantage. According to Moreira and Iao (2014), several research works show various benefits associated with having repeat visitors to a destination which include offering a stable market for the destination and free advertising to family members and friends in the form of word-of-mouth recommendations. This situation allows for the generation of rents, as the influx of tourists increase local income directly (accommodation, food and 
levantnost prihoda stanovništva kao kritičnu varijablu. Stoga u literaturi o konkurentnosti turizma postoji suglasnost o načelu da konkurentnost destinacije prethodi ekonomskom blagostanju i napretku lokalnog stanovništva (Mazanec, Wöber i Zins, 2007). Zbog toga je važno uzeti u obzir da se u upravljanju baštinom često javljaju nejednakosti i da članovi zajednice mogu imati osjećaj da su žrtve baštinskih projekata (Logan, 2012). Na istom tragu Lixinski (2013) brani zajednice tvrdeći da se koristi iskorištavanja nematerijalne kulturne baštine moraju vraćati u zajednice iz kojih potječu, a to ukazuje na relevantnost prisvajanja rente.

Ponos i druge inicijative povezane s prijenosom inherentnog znanja nematerijalne kulturne baštine, iako nije obavezno povezano s potrebom dobivanja rente, može se smanjiti činjenicom da pokretači izvan zajednice dobivaju većinu koristi od iskorištavanja lokalnog znanja. Zapravo, neke autohtone skupine mogu se suprotstavljati dokumentiranju njihovog intelektualnog vlasništva jer dokumentiranjem njihovo vlasništvo lako može izmaći njihovim rukama (Byrne, 2009). Grant (2002) potvrđuje da je logična pretpostavka da vlasnici resursa trebaju dobiti svoju rentu, ali upozorava i na probleme vezane uz probleme prisvajanja tih renti. S teritorijalne točke gledišta, mnogi sudionici i vanjske tvrtke mogu steći značajne udjele u rentama generiranim u destinacijama koje se temelje na nematerijalnoj baštini. Potrebna je prisutnost i aktivnosti mnogih vanjskih tvrtki jer lokalne ne mogu osigurati robe i usluge koje su potrebne u turizmu, ali u nekim drugim slučajevima lokalne tvrtke bi također mogle ponuditi usluge u izravnoj konkurenciji s vanjskima. Ritchie i Crouch (2010) zaključuju da stupanj utjecaja razvoja turizma na ekonomski prosperitet i kvalitetu života stanovništva značajno ovisi o djelovanju i uspjehu mnogih malih i srednjih poduzeća. Na isti način Croes i Kubickova (2013) ukazuju na relevantnost kvalitete života stanovništva kao rezultata turističke kompetentnosti. Nji- beverage, etc.) and indirectly. Income from tourism is enhanced, which is coherent with many models of destination competitiveness which stress the relevance of residents' income as a critical variable. Thus, in the literature of tourism competitiveness, there is a consensus on the tenet that destination competitiveness is an antecedent to economic welfare and prosperity of the resident population (Mazanec, Wöber and Zins, 2007). It is then important to consider that inequities often arise in the process of heritage management, and the community members can have the feeling that they are the victims of heritage projects (Logan, 2012). In the same line, Lixinski (2013) defends that the benefits of the exploitation of intangible cultural heritage must return to the communities where it stems from. This points to the relevance of rent appropriation.

The pride and other incentives associated with the transmission of the underlying knowledge of intangible cultural heritage, though not necessarily linked to the need for obtaining rents, can be reduced by the fact that agents outside the community receive most of the benefits of the exploitation of local knowledge. In fact, some indigenous groups may oppose their intellectual property documented, because once documented its ownership easily passes out of their hands (Byrne, 2009). Grant (2002) affirms that a logical assumption is that the owner of the resources should get their rents but this author goes on to address the problems associated with the problems of rent appropriation. From a territorial point of view, many agents and external firms can obtain significant shares of the rents generated at an intangible heritage-based destination. The presence and activities of many of those external firms are required because local firms cannot provide the goods and services needed for the tourism industry, but in some other cases local firms could also offer some services in direct competition with these external firms. For Ritchie and Crouch (2010), 
ma se čini da specijalizacija turizma potiče više standarde života, a time se i odražavaju više razine turističke konkurencije.

\section{RASPRAVA I ZAKLJUČCI}

Namjera rada bila je prikazati nematerijalnu kulturnu baštinu kao dragocjeno znanje koje može postati temelj održivih konkurentskih prednosti u destinaciji. U ovom teoretskom pregledu vrednovalo se zanimanje za analizu upravljanja i konkurentnost nematerijalne kulturne baštine s ciljem unaprjeđenja dobrobiti zajednice, iako se znanstvena literatura primarno fokusira na definiciju i značenje termina. Kao što istraživanja mogu imati kreativnu snagu izgradnje i strukturiranja turizma (Tribe, 2006), literatura na teme menadžmenta i turizma, posebno u odnosu na upravljanje znanjem i imidžem, može doprinijeti boljem razumijevanju potencijalne konkurentnosti nematerijalne kulturne baštine.

Nakon rasprave o posebnim aspektima koji utječu na stvaranje i održivost konkurentskih prednosti destinacija nematerijalne kulturne baštine te generiranja i prisvajanja renti koje proizlaze iz tih prednosti, Slika 1 daje sažetak predloženog pristupa. Da bi postojala konkurentska prednost, inherentno znanje o nematerijalnoj kulturnoj baštini mora biti oskudno i relevantno. $\mathrm{S}$ jedne strane, oskudnost se veže s činjenicom da mnoge druge destinacije nemaju to inherentno znanje. S druge strane, relevantna nematerijalna baština odnosi se na primamljivi imidž kojeg cijeni značajan segment turista. Destinacijski menadžeri trebaju procijeniti resurse desti- the extent to which tourism development advances economic prosperity and the quality of life of residents is significantly dependent on the actions and success of many small to medium sized enterprises. In that same line, Croes and Kubickova (2013) also outline the relevance of the residents' quality of life as an output of tourism competiveness. For them, tourism specialization seems to propel higher standards of living and hence reflecting higher levels of tourism competitiveness.

\section{DISCUSSION AND CONCLUSIONS}

This work has tried to view intangible cultural heritage as valuable knowledge capable of becoming the basis of sustainable competitive advantages at a destination. This theoretical review has validated the interest for analyzing management and competitiveness of intangible cultural heritage in order to improve the community's wellbeing, though the academic literature has primarily focused on the definition and the implication of the term. As research can have the creative power to construct and frame tourism (Tribe, 2006), the literature on management and tourism, especially regarding knowledge management and image, can contribute to a better understanding of the potential competitiveness of intangible cultural heritage.

After discussing specific aspects that affect the creation and sustainability of competitive advantages in intangible cultural heritage destinations, and rent generation and appropriation derived from those advantages, Figure 1 summarizes the proposed approach. In order to establish a competitive advantage, the knowledge underlying intangible cultural heritage has to be scarce and relevant. On the one hand, scarcity is related to the fact that the underlying knowledge is not possessed by many other destinations. On the other hand, relevant intangible heritage refers to an appealing image that is valued by a significant segment of tourists. 
nacije koji prelaze ono materijalno i vidljivo kako bi identificirali nematerijalne kulturne elemente koji su oskudni i potencijalno privlačni. Evaluacija te nematerijalne baštine prema UNESCO-vim kriterijima je zanimljiv, izvanredan mehanizam kojim se može pokazati njezina potencijalna oskudnost, ali postoje mnoge nematerijalne kulturne manifestacije i prakse koje su značajne bez obzira na to jesu li uvrštene na UNESCO-ve popise - barem s gledišta turizma. U tom smislu analiza relevantnosti nematerijalne kulturne baštine također treba biti strateška djelatnost organizacija destinacijskog menadžmenta, kao što i osnaživanje te potencijalne relevantnosti mora biti strateški pravac marketinških planova.
Destination managers should assess the resources of the destination going beyond the tangible, apparent ones to identify intangible cultural elements, which are scarce and potentially attractive. The evaluation of that intangible heritage against the UNESCO criteria is an interesting, outstanding mechanism to show its potential scarcity, but many intangible cultural manifestations and practices are significant regardless their inclusion on the UNESCO's listings, at least from the tourism perspective. In that sense, the analysis of the intangible cultural heritage relevance should be also a strategic activity for destination management organizations, and the enhancement of that potential relevance must be a strategic line in marketing plans.

Slika 1: Model značajki nematerijalne kulturne baštine za osnaživanje konkurentnosti u destinaciji

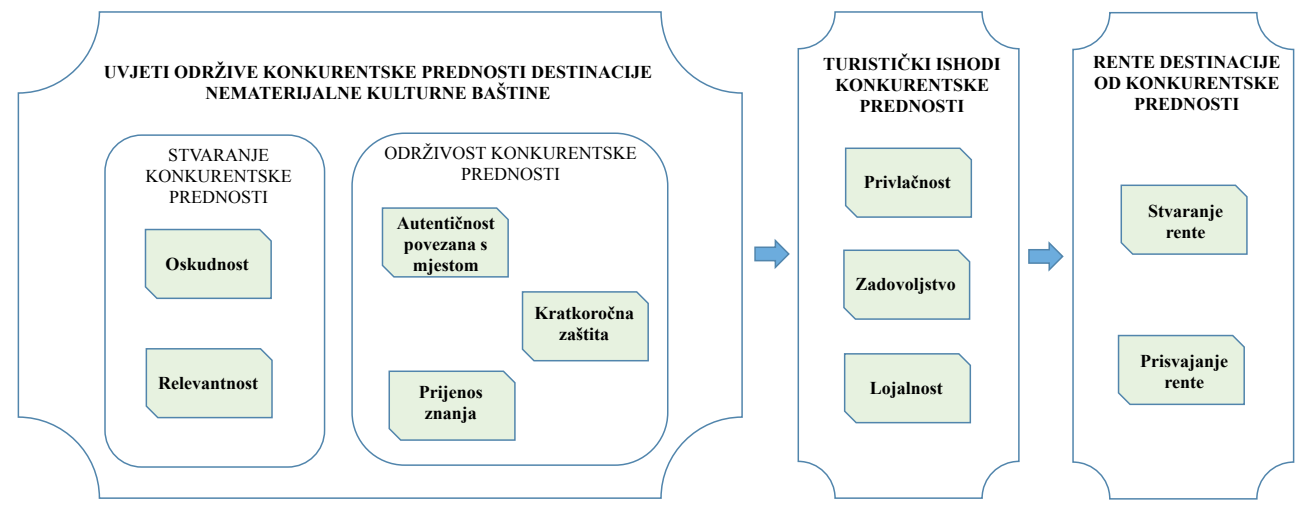

Figure 1: Model of characteristics of intangible cultural heritage to improve competitiveness in a destination

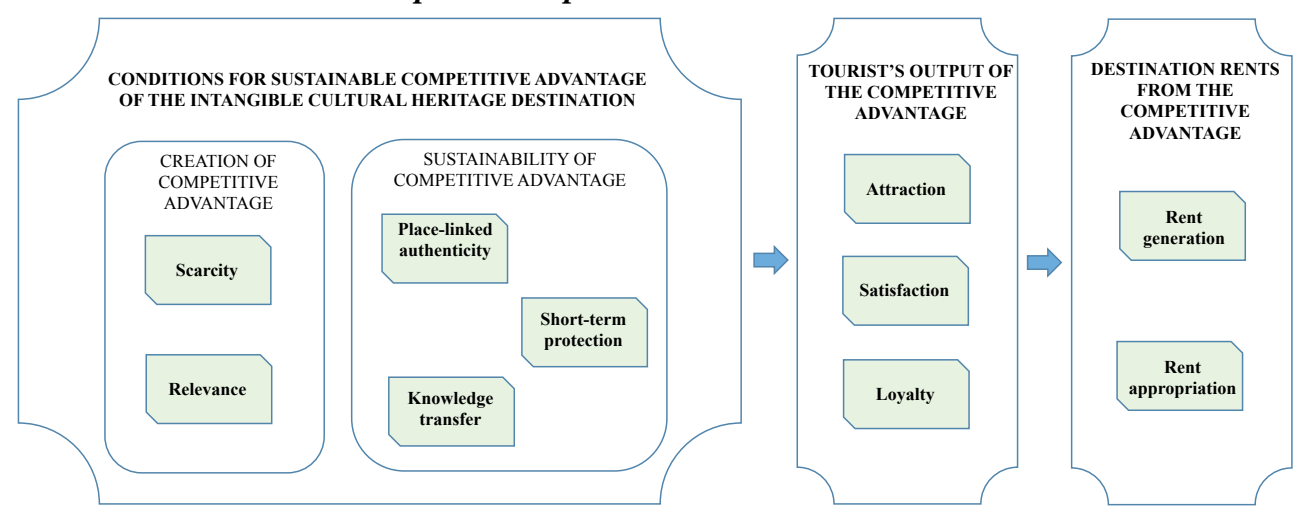


Model sa Slike 1 direktno je prenosiv u domenu empirijskog vrednovanja, a uvjeti pripremaju teren za vrednovanje lokalnih stanovnika u odnosu na relevantnost i oskudnost. Metode intervjua, kao što je Metoda utemeljene teorije, može otkriti lokalne stavove prema vrijednosti određenog resursa nematerijalne kulturne baštine. To će dovoditi do rezultata koji se onda mogu koristiti za određivanje tržišnosti bilo kojeg resursa nematerijalne kulturne baštine. Tržišnost, kao i financijski i ljudski resursi uloženi u kreiranje resursa nematerijalne kulturne baštine u atrakciju nekog kraja, određuju buduće rente od korištenja u kontekstu turizma. Kao ilustracija primjene modela u određenoj destinaciji koja ima nematerijalnu kulturnu baštinu, može se analizirati zvižduk otoka Gomera iz perspektive izložene u ovome radu. Gomerski zvižduk je jezik kojim se komunicira u planinskom području jednog od Kanarskih otoka (La Gomera). Taj zvižduk nije najvažnija atrakcija za inozemne turiste koji dolaze na otoke u potrazi za ugodnom klimom i planinarenjem, ali je relevantna atrakcija za neke stanovnike Kanarskih otoka i neke druge obrazovane kulturne turiste iz Španjolske i drugih zemalja koji žele putovati s namjerom slušanja tog jezika. U pogledu uspostavljanja konkurentske prednosti, na svijetu ne postoji mnogo zviždećih jezika koji se koriste pa je Gomerski zvižduk 2009. godine uvršten u UNESCO-ov Reprezentativni popis nematerijalne kulturne baštine čovječanstva. Dobro je poznat na Kanarskim otocima i dio je subjektivne percepcije mnogih turista na otocima. S obzirom na održivost, zvižduk se često izvodi u prirodnom okolišu otoka kako bi se pokazala komunikativna snaga i pojačali njegovi atributi autentičnosti. Štoviše, iako se jezik obično prenosio s roditelja na djecu, otočke su vlasti uvele tečajeve u obavezne škole kako bi se sačuvao ovaj običaj nematerijalne kulturne baštine. Iako bi ekonomska evaluacija turističkih renti koje generira zvižduk zahtijevala dublju analizu, Gomeranci su ponosni na
It is a straightforward exercise to move the model, depicted in Figure 1, into the realm of empirical assessment. Conditions set the stage for an assessment of local people regarding issues of relevance and scarcity. Interviews using methods such as Grounded Theory can unearth local attitudes toward the value of a particular intangible cultural heritage resource. This will lead to outputs that can then be used to determine the marketability of any intangible cultural heritage resource. Marketability including financial and human resources devoted to making the intangible cultural heritage resource into an area attraction determine future rents from its utilization in a tourism context. To illustrate the application of the model in a specific destination with intangible cultural heritage, the Gomeran whistle, could be analyzed from the perspective explained in this work. It is a whistle language spoken in one of the Canary Islands (La Gomera) and used to communicate in the mountainous regions of the island. The whistle is not the most important attraction for international visitors coming to the island in search of a nice climate and hiking possibilities, but it is a relevant attraction for some Canarians who want to travel there to listen to it, and some other Spanish and knowledgeable cultural tourists. Regarding the establishment of a competitive advantage, not many whistle languages are employed in the world and the Gomeran whistle was included on the Representative List of the Intangible Cultural Heritage of Humanity in 2009. It is well known on the Canary Islands and it forms part of the subjective perception of many visitors to the island. With regard to sustainability, the whistle exhibitions on the island often use the natural setting of the island to show its communicative power and enhancing its authenticity attributes. Moreover, the language was usually transmitted from parents to children, but the island government has included the whistle in courses offered in official schools to safeguard these intangible 
svoj zviždeći jezik. Vrijednost ovog oblika nematerijalne kulturne baštine lako bi se mogla empirijski vrednovati kao turistička atrakcija iz informacija dobivenih od lokalnih otočana.

Konkurentska prednost mora se održati kako bi generirala rente na dugi rok. Za to su relevantna tri aspekta u kontekstu znanja nematerijalne baštine: autentičnost povezana sa specifičnom destinacijom, kratkoročna zaštita u svrhu očuvanja osnovnog znanja i prijenos znanja novim generacijama. Organizacije destinacijskog menadžmenta također imaju ulogu u povezivanju nematerijalne kulturne baštine sa specifičnim geografskim područjem njezinog nastanka i razvoja. $\mathrm{S}$ druge strane, kulturni subjekti i agencije u destinaciji moraju oblikovati i prilagođavati planove zaštite za očuvanje običaja i inherentnog znanja nematerijalne kulturne baštine, kao i prijenos znanja među generacijama. U tom procesu ključna je tema motiviranje primatelja znanja.

Posjedovanje komparativnih prednosti temeljenih na nematerijalnoj kulturnoj baštini destinacije povezano je s pozitivnim rezultatima za destinaciju. Kao što ukazuju neki radovi o konkurentnosti destinacija, ti prihodi u destinaciji odnose se na turističke atrakcije, zadovoljstvo i ponovne posjete. Ako se ti rezultati povećavaju, stvaraju se rente dobivene iz održivog korištenja nematerijalnih resursa na kojima se temelje konkurentske prednosti (Grant, 2002). Dakako, te rente moraju se bar djelomično podijeliti članovima zajednice koja posjeduje nematerijalnu kulturnu baštinu. Menadžeri destinacija temeljenih na nematerijalnoj baštini mogli bi to objasniti kao potrebu osnaživanja poduzetništva i postojanja lokalnih poduzeća kao načina kako bi lokalno stanovništvo povećalo rente iznad pukih prihoda od rada. Ovime bi se također mogla učvrstiti motivacija za zadržavanje i iskorištenje inherentnog znanja zajednice na održivi način. Međutim, treba uzeti u obzir i činjenicu da konkurencija nema uvijek pozitivne posljedice. practices. Though the economic evaluation of tourism rents generated by the whistle would require a deep analysis, Gomerans are proud of their whistle language. This form of intangible cultural heritage would easily lend itself to an empirical assessment of its value as a tourism attraction with information gleaned from the local islanders.

The competitive advantage must be sustained in order to generate long-term rents. Three aspects are relevant for that in the context of the intangible heritage knowledge: the authenticity linked to a specific destination, the short term-protection regarding the maintenance of the core knowledge, and knowledge transfer to the newer generations. Destination management organisations have also a role in linking the intangible cultural heritage to the specific geographical zone where it has been generated and evolved. On the other hand, cultural entities and agencies at the destination must design and revise protection plans to safeguard the practices and underlying knowledge of intangible cultural heritage, including the inter-generational knowledge transfer. The incentives regarding the knowledge recipients are arguably the key topic in that process.

The possession of sustainable competitive advantages based on the destination's intangible cultural heritage is related to positive outputs for the destination. As some works on destination competitiveness suggest, those outputs in the destination arena are related to tourists' attraction, satisfaction, and repeated visits. If those outputs are enhanced, rents derived from the sustainable exploitation of the intangible resources which are the base of the competitive advantages are generated (Grant, 2002). However, those rents must be at least partially appropriated by members of the community that holds the intangible cultural heritage. Destination managers in intangible heritage-based destinations could interpret that as a need to encourage entrepreneurship and the existence of local firms as a way to improve rent appropriation by lo- 
Budućnost nematerijalne kulturne baštine u kontekstu turizma, nedvojbeno ce se svesti na to koliko ekonomske koristi ima lokalna zajednica od zaštite nečega što je relevantno njihovim životima. Razvojne sile su neumoljive. Sačuvati nešto kao simbol mjesta, vremena ili temelja znanja zahtijevat će razumijevanje njegovog relativnog značaja za ponos zajednice, način života, kao i za buduće mogućnosti zarade. U ovome se radu razmotrio koncept nematerijalne kulturne baštine i njezine relevantnosti za konkurentski turistički sustav destinacije. Veze koje ljude privlače drugim načinima života, koji su često strani onima otkuda su oni došli, nastavit će nuditi autentičnosti i uvid u drugačije kulture bez obzira na to koliko sveprisutnost društvenih medija i virtualna stvarnost postanu dijelom naših života.

\section{LITERATURA - REFERENCES}

Aikawa, N. (2004). An Historical Overview of the Preparation of the UNESCO International Convention for the Safeguarding of the Intangible Cultural Heritage. Museum International, Vol. 56, No. 1-2, pp. 137-149. DOI: https://doi.org/10.1111/ j.1350-0775.2004.00468.x

Alavi, M., Leidner, D. E. (2001). Knowledge management and knowledge management systems: Conceptual foundations and research issues. MIS Quarterly, Vol. 25, No. 1, pp. 107-136. DOI: https://doi. org/10.2307/3250961

Alberti, F. G., Giusti, J. D. (2012). Cultural heritage, tourism and regional competitiveness: The Motor Valley cluster. cals beyond mere labor rents. This also could reinforce motivation to retain and exploit the intangible knowledge of the community in a sustainable way. However, the benefits of competition should be also taken into account and this intervention is not always positive.

The future of intangible cultural heritage, in a tourism context, will undoubtedly come down to how much locals benefit, economically, from protecting something relevant to their life story. Forces of development are relentless. To protect something as iconic of a certain place, time, or knowledge base will require an understanding of its relative importance to community pride, way of life as well as future earnings potential. In this paper we have tried to discuss the concept of intangible cultural heritage and its relevance to the competitive tourism system of a destination. Connections that draw people into a different way of life, often foreign to where they came from, will continue to offer authenticity and a glimpse into a different culture no matter how ubiquitous social media and virtual reality become in our daily lives.

City, Culture and Society, Vol. 3, pp. 261-273. DOI: https://doi.org/10.1016/j. ccs.2012.11.003

Ashworth, G. J., Tunbridge, J. E. (1990). The Tourist-Historic City. London, UK: Belhaven.

Besculides, A., Lee, M. E., McCormick, P. J. (2002). Residents' perceptions of the cultural benefits of tourism. Annals of Tourism Research, Vol. 29, No. 2, pp. $303-$ 319. DOI: https://doi.org/10.1016/S01607383(01)00066-4

Blake, J. (2014). Seven years of implementing UNESCO's 2003 Intangible Heritage Convention - Honeymoon period or the "seven-year itch"? International Journal of Cultural Property, Vol. 21, str. 291-304. DOI: https://doi.org/10.1017/ S0940739114000113 
Boude Figueredo, O., Luna, M. (2013). Gestión del conocimiento: salvaguardia del Patrimonio Cultural Inmaterial del Carnaval de Barranquilla. Opción, Vol. 29, No. 71, pp. 27-44.

Brown, J. S., Duguid, P. (1991). Organizational learning and communities-of-practice: Toward a unified view of working, learning, and innovation. Organization Science, Vol. 2, No. 1, pp. 40-57. DOI: https://doi.org/10.1287/orsc.2.1.40

Byrne, D. (2009). A critique of unfeeling heritage. In: Smith, L. and Akagawa, N. (eds) Intangible Heritage. New York: Routledge, pp. 229-252.

Chen, G. F. (2014). Intangible cultural heritage preservation: An exploratory study of digitization of the historical literature of Chinese Kunqu opera librettos. Journal on Computing and Cultural Heritage, Vol. 7, No. 1, pp. 4:1-4:16. DOI: https:// doi.org/10.1145/2583114

Cominelli, F., Greffe, X. (2012). Intangible cultural heritage: Safeguarding for creativity. City, Culture and Society, Vol. 3, pp. 245-250. DOI: https://doi.org/10.1016/j. ccs.2012.10.003

Condominas, G. (2004). Researching and safeguarding the intangible heritage. $\mathrm{Mu}$ seum International, Vol. 56, No. 1-2, pp. 21-31. DOI: https://doi.org/10.1111/j.13500775.2004.00454.x

Cooper, C. (2006). Knowledge management and tourism. Annals of Tourism Research, Vol. 33, No. 1, pp. 47-64. DOI: https:// doi.org/10.1016/j.annals.2005.04.005

Croes, R., Kubickova, M. (2013). From potential to ability to compete: Towards a performance-based tourism competitiveness index. Journal of Destination Marketing \& Management, Vol. 2, No. 3, pp. 146-154. DOI: https://doi.org/10.1016/j. jdmm.2013.07.002

Datta, P., Bigham, G., Zou, Z., Hill, G. (2015). A global study of heritage site ecology, proclivity \& loyalty. Journal of Hospitality and Tourism Management (published online). DOI: https://doi.org/10.1016/j. jhtm.2014.12.002

Del Barrio, M. J., Devesa, M., Herrero, L. C. (2012). Evaluating intangible cultural heritage: The case of cultural festivals. City, Culture and Society, Vol. 3, pp. 235-244. DOI: https://doi.org/10.1016/j. ccs.2012.09.002

Duvelle, C. (2013). Intangible cultural heritage convention: 10 years of implementation. International Journal of Intangible Heritage, Vol. 8, pp. 8-11.

Eisenhardt, K. M., Santos, F. M. (2002). Knowledge-based view: A new theory of strategy. Handbook of strategy and management, Vol. 1, pp. 139-164. DOI: https://doi.org/10.4135/9781848608313.n7

Eoin, L. N., King, R. (2013). How to develop intangible heritage: the case of Metolong Dam, Lesotho. World Archaeology, Vol. 45, No. 4, pp. 653-669. DOI: https://doi.or $\mathrm{g} / 10.1080 / 00438243.2013 .823885$

Enright, M. J., Newton, J. (2004). Tourism destination competitiveness: A quantitative approach. Tourism Management, Vol. 25, No. 6, pp. 777-788. DOI: https:// doi.org/10.1016/j.tourman.2004.06.008

Fu, Y., Kim, S., Zhou, T. (2015). Staging the 'authenticity' of intangible heritage from the production perspective: the case of craftsmanship museum cluster in Hangzhou, China. Journal of Tourism and Cultural Change, Vol. 13, No. 4, pp. 285-300. DOI: https://doi.org/10.1080/14766825.20 14.983439

García-Almeida, D. J. (2011). Dirección de empresas turísticas. Las Palmas de Gran Canaria, Spain: Universidad de Las Palmas de Gran Canaria.

Gartner, W. C. (1993). Image Formation Process. Journal of Travel and Tourism Marketing, Vol. 2, No. 3, pp. 191-212. DOI: https://doi.org/10.1300/J073v02n02_12 
Gartner, W. C. (2014). Brand Equity in a Tourism Destination. Place Branding and Public Diplomacy, Vol. 10, pp. 108-116. DOI: https://doi.org/10.1057/pb.2014.6

Gonzalez, M. V. (2008). Intangible heritage tourism and identity. Tourism Management, Vol. 29, No. 4, pp. 807-810. DOI: $\quad$ https://doi.org/10.1016/j.tourman.2007.07.003

Grant, R. M. (1996). Prospering in dynamically-competitive environments: Organizational capability as knowledge integration. Organization Science, Vol. 7, pp. 375-387. DOI: https://doi.org/10.1287/ orsc.7.4.375

Grant, R. M. (2002). Contemporary strategy analysis. Concepts, techniques, applications. Oxford, UK: Blackwell Publishers.

Grant, R. M., Jordan J. (2012). Foundations of strategy. West Sussex, UK: John Wiley \& Sons.

Harrison, R., D. B. Rose. (2010). Intangible Heritage. In Understanding Heritage and Memory, edited by T. Benton, 238-276. Manchester, UK: Manchester University Press.

Kaufmann, N. (2013). Putting intangible heritage in its place(s): Proposals for policy and practice. International Journal of Intangible Heritage, Vol. 8, pp. 19-36.

Keitumetse, S. O. (2011). Sustainable development and cultural heritage management in Botswana: Towards sustainable communities. Sustainable Development, Vol. 19, pp. 49-59. DOI: https://doi. org/10.1002/sd.419

Kranjčević, J., Gartner, W. G. (2019). Sectoral Heritage Characteristics for Wine Region Development: The Influence of Agriculture, Culture and Tourism. Acta Turistica, Vol. 31, No. 1, pp. 7-34. DOI: https://doi.org/10.22598/at/2019.31.1.7

Kurin, R. (2004). Museums and intangible heritage: Culture dead or alive? ICOM News, Vol. 57, No. 4, pp. 7-9.
Lazzeretti, L., Capone, F., Cinti, T. (2011). Open innovation in city of art: The case of laser technologies for conservation in Florence. City, Culture and Society, Vol. 2, pp. 159-168. DOI: https://doi.or$\mathrm{g} / 10.1016 / \mathrm{j} . c c s .2011 .09 .001$

Leonard, D., Sensiper, S. (1998). The role of tacit knowledge in group innovation. California Management Review, Vol. 40, pp. 112-132. DOI: https://doi. org/10.2307/41165946

Li, L. (2012). Does intangible cultural heritage law resolve everything in China? Journal of International Commercial Law and Technology, Vol. 7, No. 4, pp. 355-362.

Lixinski,L.(2013).Intangible culturalheritage in international law. Oxford, UK: OUP Oxford. DOI: https://doi.org/10.1093/acpr of:oso/9780199679508.001.0001

Logan, W. (2012). Cultural diversity, cultural heritage and human rights: towards heritage management as human rights-based cultural practice, International Journal of Heritage Studies, Vol. 18, No. 3, pp. 231-244. DOI: https://doi.org/10.1080/13 527258.2011.637573

MacCannell, D. (1973). Staged authenticity: Arrangements of social space in tourist settings. American Journal of Sociology, Vol. 79, No. 3, pp. 589-603. DOI: https:// doi.org/10.1086/225585

Mazanec, J. A., Wöber, K., Zins, A. H. (2007). Tourism destination competitiveness: From definition to explanation?. Journal of Travel Research, Vol. 46, pp. 86-95. DOI: https://doi. org/10.1177/0047287507302389

Moreira, P., Iao, C. (2014). A longitudinal study on the factors of destination image, destination attraction and destination loyalty. Journal of Social Sciences, Vol. 3, No. 3, 90-112.

Mosammam, H. M., Sarrafi, M., Nia, J. T. (2019). Measuring the competitiveness 
of Iran's health tourism. International Journal of Tourism Policy, Vol. 9, No. 3, pp. 201-221. DOI: https://doi.org/10.1504/ IJTP.2019.104875

Nasser, N. (2003). Planning for urban heritage places: Reconciling conservation, tourism, and sustainable development. Journal of Planning Literature, Vol. 17, No. 4, pp. 467-479. DOI: https://doi. org/10.1177/0885412203017004001

Pereira Roders, van Oers, R. (2011). Editorial: bridging cultural heritage and sustainable development. Journal of Cultural Heritage Management and Sustainable Development, Vol. 1, No. 1, pp. 5-14. DOI: https://doi. org/10.1108/20441261111129898

Pfeilstetter (2015). Heritage entrepreneurship. Agency-driven promotion of the Mediterranean diet in Spain. International Journal of Heritage Studies, Vol. 21, No. 3, pp. 215-231. DOI: https://doi.org/10.10 80/13527258.2014.930502

Pike, S. (2002). Destination Image Analysis-A review of 142 papers from 1973-2000. Tourism Management, Vol. 23, No. 5, pp. 541-549. DOI: https://doi. org/10.1016/S0261-5177(02)00005-5

Pike, S. (2008). Destination marketing. An integrated marketing communication approach. Oxford, UK: Butterworth-Heinemann.

Poulios, I. (2010). Moving beyond a values-based approach to heritage conservation. Conservation and Management of Archaeological Sites, Vol. 12, No. 2, pp. 170-185. DOI: https://doi.org/10.1179 /175355210X12792909186539

Ram, Y., Björk, P., Weidenfeld, A. (2016). Authenticity and place attachment of major visitor attractions. Tourism Management, Vol. 52, pp. 110-122. DOI: https://doi.org/10.1016/j.tourman.2015.06.010

Ritchie, J. R. B., Crouch, G. I. (2010). A model of destination competitiveness/ sustainability: Brazilian perspectives. Revista de Administraçao Publica, Vol. 44, No. 5, pp. 1049-1066. DOI: https://doi. org/10.1590/S0034-76122010000500003

Ryglová, K., Rašovská, I., Šácha, J., Maráková, V. (2018). Building customer loyalty in rural destinations as a pre-condition of sustainable competitiveness. Sustainability, Vol. 10, No. 4, pp. 957. DOI: https://doi.org/10.3390/su10040957

Sam, D. L., Berry, J. W. (2010). Acculturation: When individuals and groups of different cultural backgrounds meet. Perspectives on Psychological Science, Vol. 5, No. 4, pp. 472-481. DOI: https://doi. org/10.1177/1745691610373075

Sasaki, M. (2010). Opening up new horizons of urban studies. City, Culture and Society, Vol. 1, pp. 1-2. DOI: https://doi. org/10.1016/j.ccs.2010.07.002

Tasci, A. D. A., Gartner, W. C. (2007). Destination image and its functional relationships. Journal of Travel Research, Vol. 45, No. 4, pp. 413-425. DOI: https://doi. org/10.1177/0047287507299569

Teece, D. J. (1981). The market for know-how and the efficient transfer of technology. Annals of the American association of Political and Social Sciences, Vol. 458 (November), pp. 81-96. DOI: https://doi. org/10.1177/000271628145800107

Tribe, J. (2006). The truth about tourism. Annals of Tourism Research, Vol. 33, No. 2, pp. 360-381. DOI: https://doi.org/10.1016/j.annals.2005.11.001

UNESCO (2003). Convention for the Safeguarding of the Intangible Cultural Heritage. Paris, France: UNESCO.

UNESCO (2016). Available at www.unesco. org/culture/ich/en/lists?multinational=3\&displayl $=$ inscriptionID\&display $=$ stat s\#tabs [Accessed in July 2016]

UNWTO (2012). Tourism and Intangible Cultural Heritage. Madrid, Spain: UNWTO. 
Vakhitova, T. V. (2015). Rethinking conservation: managing cultural heritage as an inhabited cultural landscape. Built Environment Project and Asset Management, Vol. 5, No. 2, pp. 217-228. DOI: https:// doi.org/10.1108/BEPAM-12-2013-0069

Van Wijk, R., Jansen, J. J. P., Lyles, M. A. (2008). Inter- and intra-organizational knowledge transfer: A meta-analytic review and assessment of its antecedents and consequences. Journal of Management Studies, Vol. 45, No. 4, pp. 815838. DOI: https://doi.org/10.1111/j.14676486.2008.00771.x

Vecco, M. (2010). A definition of cultural heritage: From the tangible to the intangible. Journal of Cultural Heritage, Vol. 11, pp. 321-324. DOI: https://doi.org/10.1016/j.culher.2010.01.006

Volberda, H. W., Foss, N. J., Lyles, M. A. (2010). Absorbing the concept of absorpti- ve capacity: How to realize its potential in the organization field. Organization Science, Vol. 21, No. 4, pp. 931-951. DOI: https://doi.org/10.1287/orsc.1090.0503

Watson, S., Waterton, E., Smith, L. (2012). Moments, instances and experiences. In Smith, L., Waterton E. and Watson, S. (eds.) The cultural moment in tourism. Oxon, UK: Routledge.

Zhou, F. (2014). Comparative legal study of intangible cultural heritage in the UK and China. Journal of International Commercial Law and Technology, Vol. 9, No. 4, pp. 269-284.

Primljeno: 9. rujna 2020./

Submitted: 9 September 2020

Prihvaćeno: 26. studenog 2020. I

Accepted: 26 November 2020 
